\title{
Igneous and Metamorphic Rocks of the
}

\section{Serpentine Hot Springs Area, \\ Seward Peninsula, Alaska}

GEOLOGICAL SURVEY PROFESSIONAL PAPER 1079

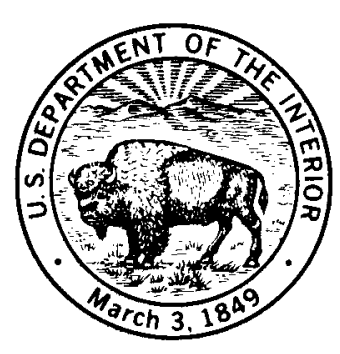

UNITED STATES PRINTING OFFICE, WASHINGTON: 1979 


\section{DISCLAIMER}

This report was prepared as an account of work sponsored by an agency of the United States Government. Neither the United States Government nor any agency Thereof, nor any of their employees, makes any warranty, express or implied, or assumes any legal liability or responsibility for the accuracy, completeness, or usefulness of any information, apparatus, product, or process disclosed, or represents that its use would not infringe privately owned rights. Reference herein to any specific commercial product, process, or service by trade name, trademark, manufacturer, or otherwise does not necessarily constitute or imply its endorsement, recommendation, or favoring by the United States Government or any agency thereof. The views and opinions of authors expressed herein do not necessarily state or reflect those of the United States Government or any agency thereof. 


\section{DISCLAIMER}

Portions of this document may be illegible in electronic image products. Images are produced from the best available original document. 


\section{UNITED STATES DEPARTMENT OF THE INTERIOR}

CECIL D. ANDRUS, Secretary

\section{GEOLOGICAL SURVEY}

H. William Menard, Director

Library of Congress Cataloging in Publication Data

Hudson, Travis

Igneous and metamorphic rocks of the Serpentine Hot Springs area, Seward Peninsula, Alaska. (Geological Survey Professional Paper 1079)

Bibliography: p. 27.

1. Granite-Alaska-Serpentine Hot Springs region. 2. Rocks, Igneous, 3. Rocks, Metamorphic. 4. Petrology-Alaska-Serpentine Hot Springs region. I. Title. II. Series: United States. Geological Survey. Professional Paper 1079. QE462.G7H83 $552^{\prime} .3$ $78-27858$

For sale by the Superintendent of Documents, U.S. Government Printing Office Washington, D.C. 20402

Stock Number 024-001-03143-4 


\section{CONTENTS}

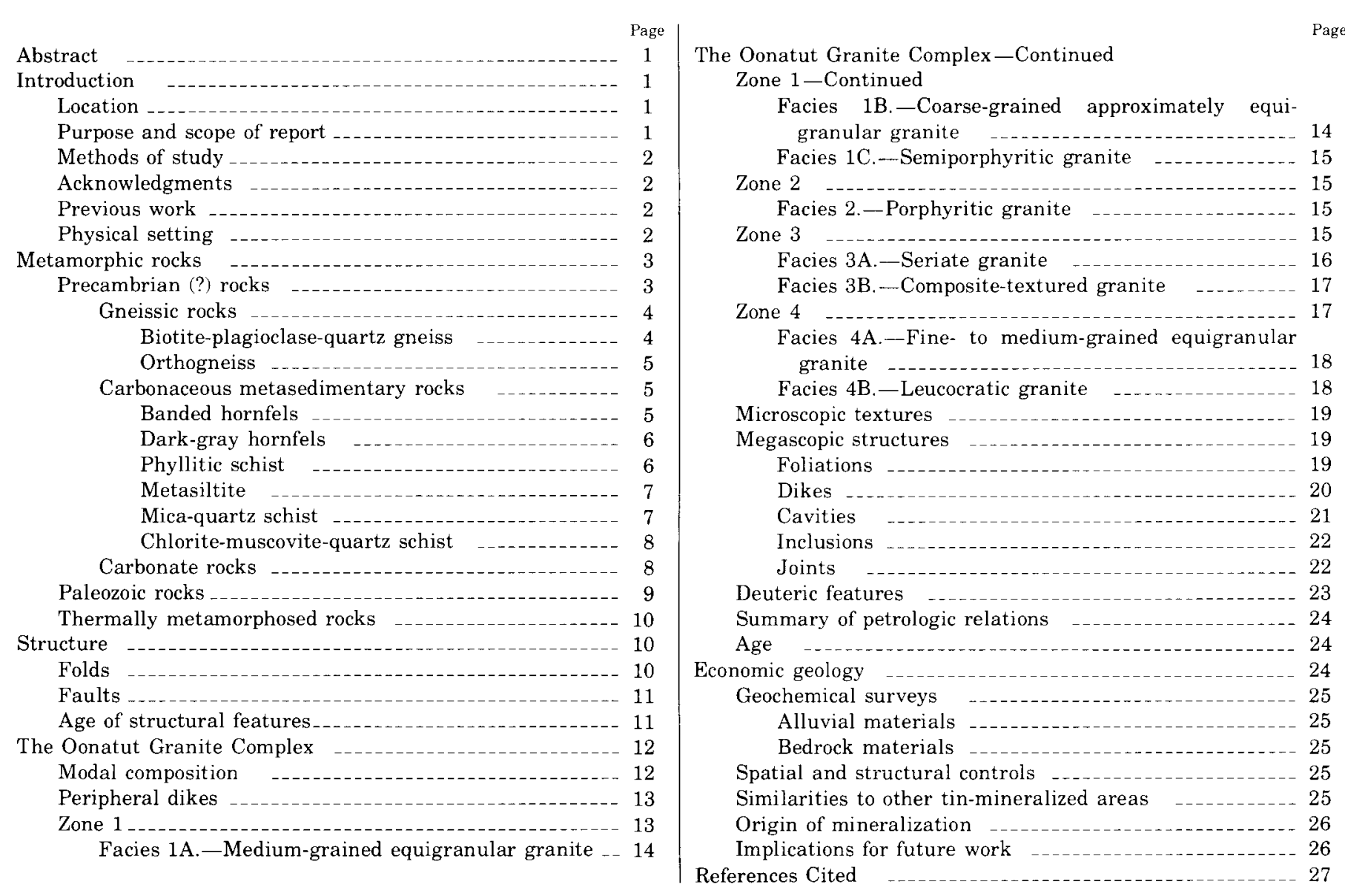

\section{ILLUSTRATIONS}

Plate 1. Geologic map and generalized cross section of the Serpentine Hot Springs area,

FIGURE 1. Index map showing location of Serpentine Hot Springs area

In pocket

2. Photograph showing southern part of the Oonatut Granite Complex

3. Photograph showing hand specimens of biotite-plagioclase-quartz gneiss and granite orthogneiss

4. Photograph showing outcrop of strongly deformed chlorite-muscovite-quartz schist

5. Photomicrograph showing complex deformation features in chlorite-muscovite-quartz schist

6. Map showing distribution of tin-granite plutons, Seward Peninsula

7-18. Photographs showing:

7. Plot of modal Pl:Q:Or ratios for samples collected from all parts of the Oonatut Granite Complex

8. Representative specimens of textural facies in zone 1

9. Representative specimens of zone 2

10. Exposed contact between facies $3 \mathrm{~A}$ and facies $3 \mathrm{~B}$

11. Representative specimens of textural facies $3 A$

12. Representative specimens of textural facies $3 \mathrm{~B}$

13. Representative specimens of textural facies in zone 4

14. Mineral segregations in facies 3A 
Figure 15. Discontinuous and branching aplite dikes in facies $3 \mathrm{~A}$

16. Composite aplite-pegmatite dik

17. Quartz-feldspar pegmatitic pod in facies $3 \mathrm{~A}$

18. Vuggy replacement selvage along walls of pocket in facies $3 \mathrm{~A}$

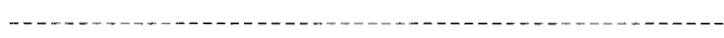

\section{TABLES}

Figure 1. Analytical data for K-Ar age determinations

2. Results of semiquantitative spectrographic analyses of composite grab samples of soil, altered rock, and gossan fragments collected along fault zone containing fine-grained dike 


\title{
IGNEOUS AND METAMORPHIC ROCKS OF THE SERPENTINE HOT SPRINGS AREA, SEWARD PENINSULA, ALASKA
}

\author{
By Travis Hudson
}

\begin{abstract}
A composite epizonal stock of biotite granite, herein named the Oonatut Granite Complex, has intruded a diverse suite of metamorphic rocks in the Serpentine Hot Springs area of northcentral Seward Peninsula, Alaska. The metamorphic rocks include amphibolite-facies gneisses, greenschist-facies fine-grained siliceous and carbonaceous metasedimentary rocks, and a variety of carbonate rocks. Lithologic units within the metamorphic terrane trend generally north-northeast and dip moderately toward the southeast. Thrust faults locally juxtapose lithologic units in the metamorphic terrane, and normal faults displace both the metamorphic rocks and some parts of the granite stock. The gneisses and carbonaceous metasedimentary rocks are probably late Precambrian, but the carbonate rocks are in part Paleozoic. Dating by the potassium-argon method indicates that the granite stock is Late Cretaceous.

The stock has sharp discordant contacts and a well-developed thermal aureole of rocks of hornblende-hornfels facies. The mode of the granite is 29 percent plagioclase, 31 percent quartz, 36 percent $\mathrm{K}$-feldspar, and 4 percent biotite. Accessory minerals include apatite, magnetite, sphene, allanite, and zircon. Late-stage or deuteric minerals include muscovite, fluorite, tourmaline, quartz, and albite.

The stock is a zoned complex containing rocks of several textural facies in four partly concentric zones. Zone 1 is a discontinuous border unit, containing fine- to coarse-grained biotite granite, that grades inward into zone 2 . Zone 2 contains porphyritic biotite granite consisting of oriented phenocrysts of pinkish-gray microcline in a coarse-grained equigranular groundmass of plagioclase, quartz, and biotite. It is in sharp, concordant to discordant contact with rocks of zone 3 . Zone 3 contains some areas of seriate-textured biotite granite but is mostly porphyritic granite containing phenocrysts of plagioclase, K-feldspar, quartz, and biotite in an aplitic groundmass. Flow structures, pegmatite and aplite segregations, and miarolitic cavities are common in the seriate-textured granite. Zone 4, which forms the central part of the complex, consists of fineto medium-grained biotite granite and locally developed leucogranite. Small miarolitic cavities are common within it.

Bedrock mineralized zones contain anomalous concentrations of tin, lead, zinc, antimony, arsenic, and silver. These zones are localized along normal faults in metamorphic rock peripheral to and above parts of the granite complex. The general geologic environment is similar to that in other tin-mineralized areas, and the mineralized zones may have formed directly from an aqueous phase that evolved during final crystallization of the granite complex and escaped along crosscutting faults.
\end{abstract}

\section{INTRODUCTION}

\section{LOCATION}

The Serpentine Hot Springs area lies $190 \mathrm{~km}$ north-northeast of Nome in the north-central part of the Seward Peninsula, Alaska (fig. 1). The area is in the headwater region of the Serpentine River, named for its meandering channel, and comprises $180 \mathrm{~km}^{2}$ in the Bendeleben D-6 and D-5 quadrangles. A maintained gravel road extends from Nome to points about $65 \mathrm{~km}$ south of Serpentine Hot Springs. The area can be reached by either track vehicle or light aircraft. The Arctic Circle is $70 \mathrm{~km}$ to the north, and Bering Strait is $160 \mathrm{~km}$ to the west (fig. 1).

PURPOSE AND SCOPE OF REPORT

This report describes the geology of the Serpentine Hot Springs area of the Seward Peninsula, Alaska, emphasizing the petrology, petrography, and mapped relations of lithologic units within a composite, epizonal biotite granite stock and the regionally metamorphosed metasedimentary rocks that surround it. Geologic relations are combined with reconnaissance geochemical data to define mineralized zones and their spatial relations to the granite stock. Chemical variations within the granite stock are integrated with the geologic data in a report that is being pre-

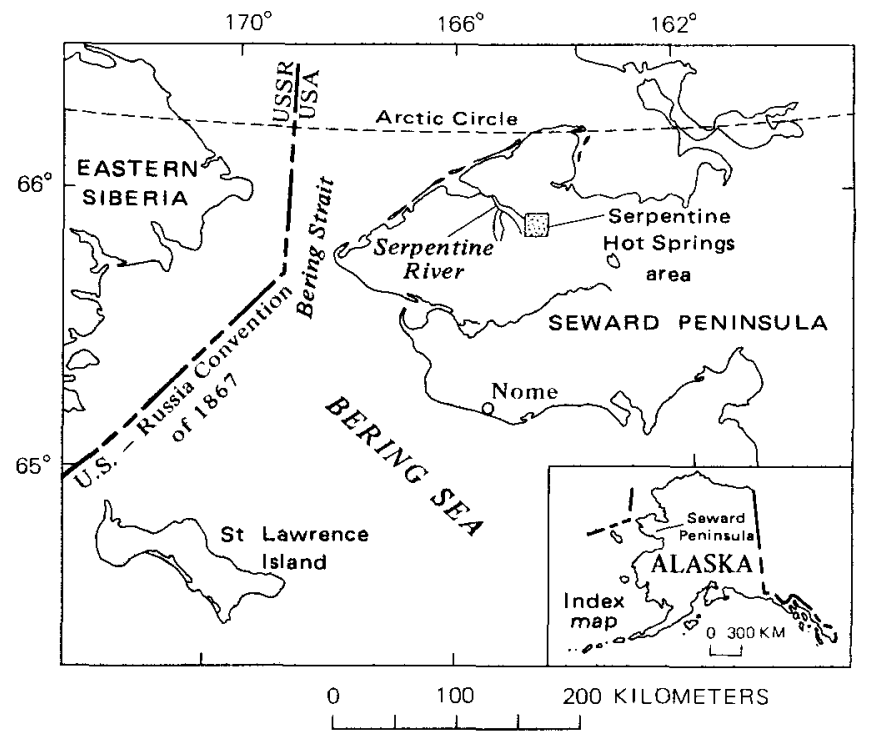

FIGURE 1.-Location of Serpentine Hot Springs area, Seward Peninsula, Alaska. 
pared separately. Many of the findings and conclusions of this study have been reported in a preliminary form (Hudson, 1977).

\section{METHODS OF STUDY}

Much of the fieldwork was done from a base camp established in a large wood frame cabin at Serpentine Hot Springs. A track vehicle served as a mobile camp for work in outlying parts of the area. The field investigations were made during the periods June 25 to July 22, 1968, June 16 to August 23, 1969, and August 10 to August 27, 1970. The 1968 work was part of a regional mapping project with principal emphases upon studies and sampling of mineralized areas (Sainsbury, Hudson, Kachadoorian, and Richards 1970), but during this time the margin of the granite complex was outlined. The major lithologic units were defined, mapped, and sampled in 1969, when systematic sampling of the granite complex on a $0.6-\mathrm{km}$ spacing also was completed. In 1970, important structural features within the complex were studied, and a transparent plastic overlay with grid points spaced 3.2 $\mathrm{cm}$ apart was used to determine modal phenocryst populations in several of the rock types. The overlay was taped to flat outcrop surfaces for the counting of more than 1,000 points at each of 23 localities.

Thin sections and hand specimens were systematically examined and described in the laboratory. Detailed examination of granite specimens was facilitated by the staining of K-feldspar on sawed slabs (Norman, 1974). The stained surfaces were point counted using transparent plastic grid overlays; maximum spacing of points was $2.5 \mathrm{~mm}$, and 800 to more than 1,000 points were counted on each slab. Plagioclase compositions were determined optically by the a-normal method with reference to curves published by Deer, Howie, and Zussman (1966, p. 333). Some mineral identifications were made by means of $\mathrm{X}$-ray diffraction powder patterns, and compositions and structural states were determined for a few $\mathrm{K}$-feldspars according to the method of Wright (1968).

\section{ACKNOWLEDGMENTS}

This work was suggested by C. L. Sainsbury and was part of a doctoral dissertation submitted to Stanford University in 1976. Richard H. Jahns and Konrad B. Krauskopf of Stanford University gave helpful suggestions and discussions during the entire study, and Jahns visited the Serpentine Hot Springs area in 1970.

During the summer of 1968 , C. L. Sainsbury, Reuben Kachadoorian, and Thomas Richards participated in the fieldwork. Clifford Weyiounna was an excellent field assistant during the 1969 season and did much of the systematic sampling of the granite com- plex. In 1970, Tom Hayward did most of the point counting in outcrop. The 1969 fieldwork was partially funded by a Penrose Bequest Research Grant from the Geological Society of America. Lowell Kohnitz photographed the hand specimens, and Norman Prime assisted in the taking of photomicrographs.

I am thankful to many friends on the Seward Peninsula for their help during various stages of the fieldwork. Special thanks go to the Tweet families of Teller who, while operating their mine near Taylor on the Kougarok River, were my closest neighbors. They made substantial efforts to help retrieve and repair disabled track vehicles, and their kindnesses and friendly hospitality will always be appreciated.

Finally, I am deeply grateful for the personal support given by Christine Allen through several years of this work and especially during the summer of 1969.

\section{PREVIOUS WORK}

Earlier field studies on the Seward Peninsula are generally of a reconnaissance nature or are directed to specific mineral deposits. Those reports pertinent to the Serpentine Hot Springs area include an overview of the regional geology by Collier (Collier and others, 1908) and Sainsbury (1975), discussions of tin occurrences throughout the peninsula by Knopf (1908b) and Steidtman and Cathcart (1922), and a detailed description of the geology of the central York Mountains by Sainsbury (1969a). Results of an aeromagnetic survey have been reported by Johnson and Sainsbury (1974), and a regional Bouguer anomaly map has been published by Barnes (1971). Regional investigations of granitic rocks in western Alaska have been made by Miller (1970) and by Csejtey, Patton, and Miller, 1971).

A brief visit to the Serpentine Hot Springs area was described by Collier (1902), who later drew attention to the potential for tin mineralization (1904a) and mentioned an unconfirmed report of lode tin in the area (1904b). Knopf (1908a) confirmed the presence of placer cassiterite on Humbolt Creek. Moxham and West (1953) visited the area in search of deposits of radioactive minerals, Sainsbury, Kachadoorian, Smith, and Todd (1968) described placer concentrates containing cassiterite from Humbolt Creek, and Sainsbury, Hudson, Kachadoorian, and Richards (1970) provided a preliminary description of the geology and the results of a more detailed investigation of mineralized areas. Some data on the thermal springs in the area were included in a report by Miller, Barnes, and Patton (1975).

\section{PHYSICAL SETTING}

The Serpentine Hot Springs area is in the Intermontane Plateau of Alaska (Wahrhaftig, 1965) and is 
characterized by a landscape of elongate, rounded ridges and hills that are in large part mantled by tundra. Where surface materials are exposed, they are dominantly frost-riven rubble. Bedrock outcrops are scarce.

The study area straddles a north-trending ridge that reaches an elevation of $790 \mathrm{~m}$ within the area and a maximum of $830 \mathrm{~m}$ at Midnight Mountain 4.8 $\mathrm{km}$ to the south. These are the highest points in a large area, and they contribute to the variability of local relief and an unusual degree of exposure of both surface materials and bedrock (fig. 2).

In areas underlain by granite, the ridges display spectacular pinnacle outcrops. In other areas, the summits and higher slopes have well-developed altiplanation terraces. Nonterraced slopes are convex except where talus rubble is abundant. The uplands are cut by ravines and gullies on steeper slopes. These merge at lower elevations into small valleys occupied by streams.

The area has an annual rainfall of 18 to $38 \mathrm{~cm}$ and receives 76 to $86 \mathrm{~cm}$ of snow (Hopkins and others, 1955). Permafrost is continuous except locally along larger streams, in the vicinity of hot springs, and in places where the surficial cover is thin, absent, lacks vegetation, or is well drained. The vegetation is dominated by herbaceous tundra (Sigafoos, 1958), although shrub tundra and thick brushy willows are locally abundant along streams.

Weathering, together with discontinuities in bedrock types, has produced some landforms especially characteristic of the area and environment. These include the negative topographic expression of the granite margin, pinnacles of granite, talus, and solifluction features. The trace of the contact between granite

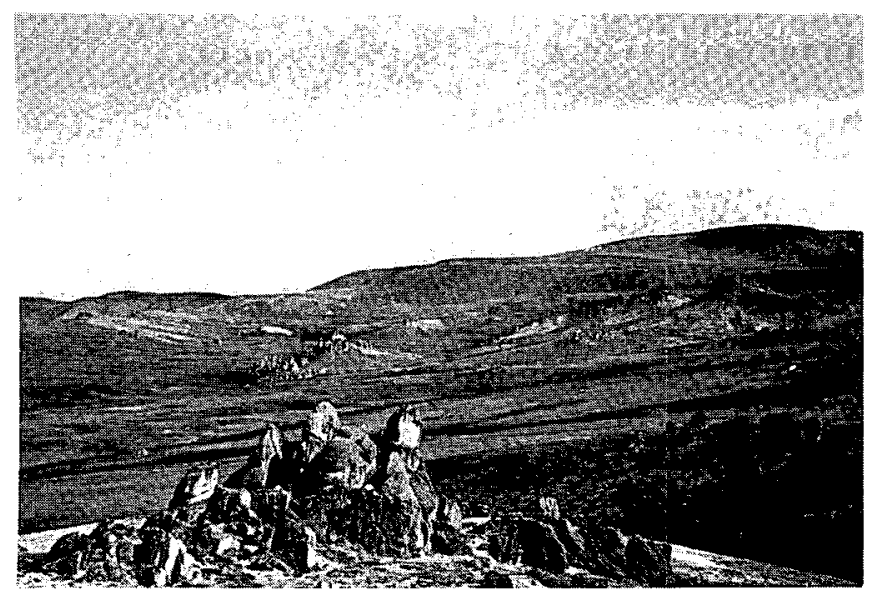

Figure 2.-Southern part of Oonatut Granite Complex, showing altiplanation terraces in metamorphic rocks beyond. Distance to far ridgeline is about $10 \mathrm{~km}$. View east. and country rocks lies on slopes that face inward toward the central parts of the granite complex. The relatively rapid rate of granite weathering and the more resistant nature of the surrounding zone of hornfels evidently have combined to produce this topography.

The prominent outcrops of granite reflect frost action and preferential weathering along joint sets. Some of the outcrops are more than $10 \mathrm{~m}$ high and are visible for many kilometers as highly anomalous irregularities in the landscape. These outcrops and their exfoliation features were first described and photographed by Collier (1902).

Talus slopes are common along margins of the steeper sided ridges and antiplanation terraces. In areas underlain by metamorphic rocks, these slopes are the places where outcrops are most likely to be found; elsewhere the bedrock is effectively mantled by rubble. In places where finer grained material occurs on the steeper slopes, well-developed solifluction lobes are present.

The streams, the larger of which are braided, are frozen during the winter except where they are warmed by hot springs. Thermal springs occur in alluvial materials of lower Hot Springs Creek at two localities (pl. 1). The spring waters are moderately mineralized and reach temperatures of $77^{\circ} \mathrm{C}$. A small undrained thaw lake, located $0.8 \mathrm{~km}$ northeast of Serpentine Hot Springs, is the only standing body of water in the area.

\section{METAMORPHIC ROCKS}

The Serpentine Hot Springs area contains a diverse suite of regionally metamorphosed rocks including amphibolite facies gneisses and greenschist facies metasedimentary rocks. The gneisses and carbonaceous metasedimentary rocks are probably late Precambrian in age, but isolated marble masses in the eastern map area are of Paleozoic age. The gneisses and carbonaceous metasedimentary rocks have been intruded and in part thermally metamorphosed by a Late Cretaceous biotite granite stock that is strongly discordant to the foliation of the metamorphic rocks.

\section{PRECAMBRIAN (?) ROCKS}

The late Precambrian (?) rocks comprise three general lithologic types: (1) gneissic rocks, (2) carbonaceous metasedimentary rocks, and (3) carbonate rocks. The gneissic and carbonaceous rocks can be subdivided into two or more distinct lithologic units. These units have been mapped (pl. 1), but poor bedrock exposure commonly prevents a clear understanding of the nature of the contacts between them. The gneissic rocks are of amphibolite-facies grade, and 
their contacts with the carbonaceous metasedimentary rocks of greenschist facies may be thrust faults. The distribution of lithologic units within the carbonaceous metasedimentary rocks probably reflects original sedimentary layering, but the tectonic history of the area is complex and unrecognized structural complications probably are present. The carbonate rocks are conformably intercalated in the carbonaceous metasedimentary rocks and probably are cogenetic with them.

GNEISSIC ROCKS

The gneissic rocks, which extend northward from the north-central granite contact, include biotiteplagioclase-quartz gneiss and granite orthogneiss. The two lithologies can be readily distinguished (fig. 3), and their separate distributions have been mapped. These amphibolite-facies rocks are texturally and mineralogically the highest grade regionally metamorphosed rocks of the area. Similar rocks have been found elsewhere on the Seward Peninsula only in the heart of the Kigluaik Mountains, $120 \mathrm{~km}$ southeast of the Serpentine Hot Springs area (Sainsbury, 1972). The gneisses in the Kigluaik Mountains have been dated radiometrically at $730 \mathrm{~m} . \mathrm{y}$., or late Precambrian (Sainsbury, Hedge, and Bunker, 1970); a similar age is inferred for the gneisses of the Serpentine Hot Springs area.

The gneisses do not crop out, but the two kinds

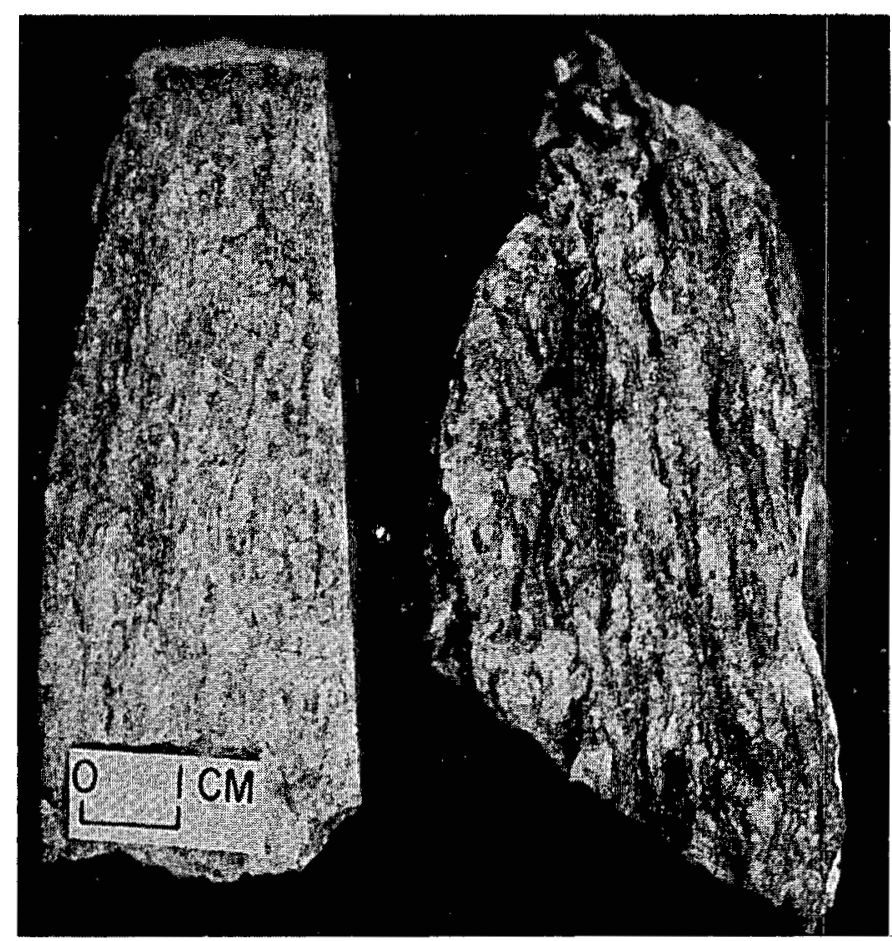

Figure 3.-Hand specimens of biotite-plagioclose-quartz gneiss (right) and granite orthogneiss (left). are not extensively intermixed in the surface rubble and the location of the contact between them is fairly distinct. The nature of this contact has not been determined, but in the Kigluaik Mountains orthogneiss is intrusive into biotite-plagioclase-quartz gneiss (Sainsbury, 1972). The sharp break in metamorphic grade between the gneiss (amphibolite facies) and the immediately adjacent carbonaceous rocks (greenschist facies), combined with the apparent absence of conglomerates and other expressions of a depositional contact, suggests that the carbonaceous rocks have been structurally juxtaposed against the gneisses.

\section{BIOTITE-PLAGIOCLASE-QUARTZ GNEISS}

Biotite-plagioclase-quartz gneiss is found adjacent to and to the north of the stock. It is mottled light brownish gray in color and fine to medium grained. Thin concentrations of fine-grained biotite are discontinuous along the foliation and outline light-colored lenses and bands rich in quartz or plagioclase. The lenses and bands are discontinuous and ordinarily are less than $0.75 \mathrm{~cm}$ in thickness. The essential minerals in order of decreasing abundance are quartz, plagioclase, and biotite. Minerals present in minor amounts include chlorite, calcite, muscovite, green amphibole, opaque mineral(s), apatite, and zircon(?).

The thin sections that were examined are from samples collected near the granite margin and show effects of thermal metamorphism. Quartz is unstrained and forms mosaics of anhedral subequant grains with simple boundaries. Plagioclase $(A n>15)$ is consistently fine grained and anhedral. It commonly is twinned and forms complexly interlocking aggregates having simple to sutured grain boundaries. Commonly it is poikilitic, and ovoid quartz is the most abundant inclusion. Biotite is pleochroic from straw yellow to dark brown, virtually inclusion free, undeformed, and has cleavages oriented both parallel and oblique to the trace of the foliation. The less abundant minerals include the accessory minerals listed above and such secondary minerals as chlorite, calcite, muscovite, and some iron hydroxides. Chlorite is interleaved with biotite, as is muscovite to a lesser extent. Muscovite more commonly occurs with calcite in fine-grained patchy aggregates of generally diversely oriented grains that replace plagioclase. Filmy reddish iron hydroxides occupy fractures and grain boundaries adjacent to other secondary minerals.

Commonly associated with the biotite-plagioclasequartz gneiss are fine-grained lineated well-foliated dark-greenish-gray amphibolites that may represent originally intercalated mafic volcanic rocks or dikes. Samples collected from near the northern granite con- 
tact contain granular clouded sphene, fine-grained granoblastic plagioclase, and green hornblende.

\section{ORTHOGNEISS}

Orthogneiss is present in the northernmost part of the map area. It is a muscovite-plagioclase-quartzmicrocline gneiss equivalent to granite in modal composition. The plagioclase:quartz:K-feldspar ratio is approximately 4:7:9. The color is a mottled light orange to gray, with the orange shades primarily due to iron hydroxide staining on grain surfaces. It is dominantly fine grained except for some microcline grains more than $1 \mathrm{~mm}$ long. Muscovite and lesser biotite are strongly oriented within segregations along the foliation. In contrast to the biotite-plagioclase-quartz gneiss, the felsic minerals do not occur in well-defined compositionally segregated lenses and bands but are more homogeneously distributed.

In thin section, the quartz grains are seen to be anhedral and the larger ones are elongate and oriented parallel to the foliation. Undulatory extinction is moderately well developed, and grain boundaries are simple to moderately complex. The plagioclase $(A n>15)$ is anhedral and angular, with poorly developed twinning that is hazy and distorted. The extinction is irregular, and some larger grains have ovoid quartz inclusions. Microcline is fine to medium grained, anhedral with interstitial boundaries, and in part semipoikilitic, including both quartz and plagioclase. Muscovite forms fine integranular grains or aggregates and is strongly oriented parallel to the trace of the foliation. Biotite is pleochroic from light tan to dark green brown and is finer grained and much less abundant than the muscovite. Minerals present in minor amounts include very fine grained granular opaque materials and subsequent anhedral zircon. Iron hydroxide is common as hazy films along nearly all fractures and grain boundaries.

\section{CARBONACEOUS METASEDIMENTARY ROCKS}

The carbonaceous metasedimentary rocks are the most abundant of the metamorphic rocks in the map area. Many different rock types are present, but the entire sequence is characterized by fine grain size, dark color, carbonaceous material, and metamorphic structures that indicate multiple deformation. These rocks are products of greenschist-facies regional metamorphism of fine-grained variably sorted thinbedded generally quartz-rich sedimentary rocks. They include many layers of calcareous schist and some thin dark-gray marble interbeds and light-gray marble lenses. Adjacent to the granite stock, thermal metamorphism has produced rocks of hornblendehornfels facies.
The carbonaceous metasedimentary rocks are part of a thick sequence which occurs throughout the Seward Peninsula. The sequence was originally called the Kuzitrin Series in the central Seward Peninsula and was correlated with similar lower grade rocks of the York Mountains by Brooks (Brooks and others, 1901). Most aspects of this correlation have been accepted by later workers, but the formal name, Kuzitrin Series, has been dropped, and the sequence as a whole is informally referred to as "slate of the York region" (Sainsbury, 1972) or simply "York Slate" (Sainsbury, 1975, p. 12). In the York Mountains, Sainsbury (1969a) described a conformable transition from Lower Ordovician limestone downward through a thick unfossiliferous section of argillaceous calcareous rocks into low-grade carbonaceous metasedimentary rocks. He concluded that the carbonaceous metasedimentary rocks of the York Mountains are late Precambrain and that, because these can be traced eastward to the Serpentine Hot Springs area, the similar but higher grade rocks in this area also are late Precambrian (Sainsbury, Hudson, Kachadoorian, and Richards, 1970, p. H6). This conclusion is not precluded by any subsequent geologic studies, but because many stratigraphic relations remain unresolved in these and other metamorphic rocks of Seward Peninsula, their age is queried in this report.

Variation in composition, texture, and response to thermal metamorphism help to define a series of roughly north-south-trending lithologic units south and east of the granite complex. The separately identified lithologic units are (1) banded hornfels, (2) dark-gray hornfels, (3) lineated phyllitic schist, (4) dark-gray metasiltite, (5) mica-quartz schist, and (6) strongly deformed chlorite-muscovite-quartz schist.

BANDED HORNFELS

Banded hornfels has been mapped in a zone along part of the eastern margin of the granite complex and in a parallel zone 40 to $45 \mathrm{~m}$ farther east. The first zone contains hornfels throughout, but the second grades into schistose rocks to the south. Overall the hornfels is medium light gray, but commonly it is partly mottled light to medium dark gray and has variably distributed brown or green tints. Banding is conspicuous in most hand specimens and is defined by color and compositional and textural variations. Individual bands are commonly less than $0.5 \mathrm{~cm}$ wide. The darker ones have a schistose foliation, whereas those that are lighter colored have a more sugary texture. In irregularly banded rocks the general fabric is more evenly schistose, and discontinuous stringy aggregates of mafic minerals are concentrated along the foliation. Also present are some light-gray marble 
beds and somewhat coarser calc-silicate schist containing variable proportions of diopside, idocrase, calcite, and plagioclase.

The thermally metamorphosed schist and hornfels are diopside-quartz-amphibole-plagioclase rocks that also contain red-brown biotite, chlorite, sphene, calcite, zircon, granular opaque materials, and cordierite. Quartz forms aggregates of anhedral grains having irregular but simple interlocking boundaries. The largest grains are poikilitic plagioclase porphyroblasts that are as much as $0.6 \mathrm{~mm}$ across. The prophyroblasts are untwinned, subequant, and have irregular boundaries, whereas smaller nonpoikilitic plagioclase displays simple twinning. Both diopside and amphibole occur between the generally larger quartz and plagioclase grains. Of the other minerals, biotite is the most common. It is diversely oriented and restricted to individual bands, as is chlorite, but the chlorite has a preferred orientation parallel to the foliation and is generally intergrown with amphibole and biotite. Dark pleochroic halos are present in some of the mafic minerals. The compositional variation between bands is dominantly the result of the preferred distribution of diopside, amphibole, and biotite.

\section{DARK-GRAY HORNFELS}

Dark-gray hornfels occurs between the two zones of banded hornfels. It is typically a schistose biotitecordierite-quartz hornfels characterized by its uniformly fine grain size and medium-dark-gray color. Most of these rocks are hard and break irregularly across schistosity. Those south of Hot Springs Creek weather to flaggy fragments that are as much as a meter across and tabular parallel to the foliation. Lithologies present in lesser amounts are dark-gray fine-grained marble with isoclinally folded quartz stringers and green fine-grained schistose mafic dikes that are also thermally metamorphosed.

Quartz occurs in aggregates of anhedral angular simply bounded grains generally with even extinction. The aggregates are elongate lenses that are oriented parallel to the foliation but also fill in "pressure shadows" adjacent to cordierite porphyroblasts. Cordierite occurs as subequant to elongate very irregularly shaped grains oriented along the foliation and riddled with inclusions of biotite, dusty to granular opaque materials, and quartz. Subequant cross sections reach $0.5 \mathrm{~mm}$ across and in part deflect the adjacent foliation. Biotite, the only mineral readily identified in hand specimen, is dark red brown in color. It has a bimodal preferred orientation parallel and approximately perpendicular to the foliation. Other minerals include muscovite, associated with biotite, and disseminated opaque material that is dominantly pyr- rhotite. The pyrrhotite has a tendency towards idiomorphic forms and is either subequant or elongate. In the latter case, the length is oriented parallel to the foliation.

\section{PHYLLITIC SCHIST}

Phyllitic schist occurs about halfway between the granite contact and Hill 2592. It is typically semilustrous medium-gray to medium-dark-gray calcitealbite-quartz-muscovite rock that weathers to platy and tabular fragments as much as $0.6 \mathrm{~m}$ or more across. Megascopically it is fine grained, carbonaceous, locally porphyroblastic, and strongly lineated. The even and pervasive schistosity is very finely crenulated, producing a strong lineation parallel to the microfold axes. Oblique to this is a second lineation produced by broader spaced folds with wave lengths between 0.6 and $1.2 \mathrm{~cm}$. An incipient second foliation has developed along the axial planes of these broader folds.

Muscovite occurs as dense felted aggregates forming bands parallel to the foliation and elsewhere as intergranular oriented grains or small aggregates. The denser aggregates display tight crenulations that have axes parallel to the strong lineation evident in hand specimens. Quartz is subequant and elongate, less than $0.35 \mathrm{~mm}$ across, and forms a few inclusions in albite porphyroblasts. The inclusions are ovoid in cross section, and intergranular grains have simple but irregularly angular boundaries. Albite, some simply twinned, occurs intergranularly with quartz or as subequant porphyroblasts as large as $1 \mathrm{~mm}$ across. The porphyroblasts are generally poikilitic with included grains, dominantly quartz, that form strings, aggregates, or elongate individuals oriented parallel to the foliation. The porphyroblasts are rounded in outline, have boundaries that are smooth and continuous, and are commonly mantled by aggregates of muscovite. Locally, intergranular subequant calcite grains up to $0.8 \mathrm{~mm}$ across constitute 10 to 15 percent of the rock. Pale chlorite having greenish-gray interference colors forms aggregates or individual grains interleaved with muscovite and makes up as much as 5 percent of a specimen. Other minerals that are present include dull-brown biotite, dusty graphite, granular disseminated opaque material that is dominantly hematite, and a minor amount of disseminated euhedral tourmaline.

In summary, this schist was originally a thin bedded argillaceous and quartz-rich rock. It is now characterized by the presence of carbonaceous material and abundant mica, microscopic compositional banding, and well-developed metamorphic structures of two distinct generations. 
METASILTITE

The most distinctive (but not dominant) rock type within the carbonaceous metasedimentary suite throughout the Seward Peninsula is a dark-gray very fine grained metasiltite that weathers to brittle rectangular fragments less than $0.3 \mathrm{~m}$ across. It consists almost wholly of quartz. Throughout the Serpentine Hot Springs area metasiltite has been mapped separately, and, although the nature of all contacts has not been determined, it is possible that there is more than one dark-gray metasiltite unit within the carbonaceous sequence.

Rocks on the west side of Hill 2592 are typical of this rock type. They are medium to dark gray, weather to platy and tabular fragments, and contain 80 to 95 percent quartz. The even grain size is less than $0.3 \mathrm{~mm}$, commonly around $0.1 \mathrm{~mm}$. Metamorphic structures, not everywhere obvious, include very thin banding, a strong lineation due to intense crenulation, and a thinly spaced regular schistosity. Where the metamorphic structures are well developed, these rocks are carbonaceous quartz schist. The schists commonly have combinations of structures indicating a polydeformational history.

Quartz typically forms equant angular grains in interlocking aggregates. Muscovite and lesser chlorite occur along quartz grain boundaries, and carbonaceous material forms disseminated dusty grains. Other minerals include tourmaline, plagioclase (some as porphyroblastic albite), epidote, and apatite.

Thermal metamorphism and physical deformation near thrust faults have produced two important textural variations. Within the thermal aureole of the granite complex, the metasiltite coarsens in grain size to a maximum of about $0.3 \mathrm{~mm}$. Banding in these rocks is better developed because opaque and micaceous material are concentrated along the foliation and because individual quartz grains have semirectangular outlines parallel to the foliation. Locally, the hornfels zone includes cordierite, brown biotite, and porphyroblastic anhedral andalusite. Where the metasiltite has been more strongly deformed, the quartz has strong undulatory extinction and complexly sutured grain boundaries. The principal foliation is commonly crenulated, and a strong lineation is developed parallel to microfold axes.

Among other variants known in the map area is a light-gray-weathering metasiltite found near the headwaters of Humbolt Creek. In thin section, the lighter colored parts of these rocks differ from the normal dark-gray parts only in the absence of fine disseminated opaque material.

Segregations and large veins of white quartz are common in the metasiltite, especially in deformed zones or near the contact with the granite. Brecciated metasiltite, encrusted with rust-colored iron hydroxides, is locally common in the surface rubble of the metasiltite unit mapped at the head of Humbolt Creek.

MICA-QUARTZ SCHIST

Mica-quartz schist occurs in a relatively wide belt that extends along strike from the granite complex across the headwaters of Ferndale Creek and past Hill 2592. This unit, which displays more lithologic variations than others in the sequence, includes chloritemuscovite-quartz schist, mica-tremolite-plagioclasequartz schist, and, in zones of thermal metamorphism, biotite-rich schist. These schists are typically a faintly brownish medium light gray, and they are lineated, fine grained, and equigranular. A strong lineation parallels the axes of microfolds, and thin compositional layering can be seen in hand specimen but is usually more obvious in thin section. Locally these schists are calcareous and contain disseminated pyrite. Oxidation of pyrite has produced spots and patches of limonite along the foliation. Thin interbeds and lenses of marble are relatively common, and near the granite complex greenish calc-silicate rocks, formed from impure calcareous interbeds, contain diopside and minor sphene and labradorite.

In thin section, these rocks are aggregates of many different minerals of variable size and distribution. As a result, they have a distinctly cluttered appearance. Quartz is equant and anhedral and has simple to sutured grain boundaries. Tremolite, where present, is the next most abundant mineral and forms prismatic, faintly greenish, irregularly terminated, and variably oriented grains less than $0.2 \mathrm{~mm}$ long. Chlorite, muscovite, and biotite together commonly compose as much as 40 percent of individual specimens. Chlorite and muscovite generally occur in stringers and aggregates parallel to the foliation, but biotite, less than 0.1 $\mathrm{mm}$ long and amber, light tan, or moderate red brown in color, is variably oriented, inclusion free, and in places interleaved with chlorite or muscovite. Both biotite and tremolite appear to be products of thermally induced recrystallization. Plagioclase forms anhedral equant grains, slightly above average in size, containing inclusions of mica and quartz. Twinning in the plagioclase is obscure to absent. Granular pyrite and other opaque materials are common, and individual grains, some up to $0.1 \mathrm{~mm}$ across, tend to be angular and subhedral. Other minerals include small euhedral tourmaline crystals, very fine grained epidote, intergranular calcite, and trace amounts of apatite and subhedral zircon.

Hornfels textures are well developed in some of these rocks adjacent to the granite complex. In these, 
porphyroblastic cordierite(?) and andalusite(?) accompany biotite, plagioclase, and quartz. The quartz is coarser than elsewhere in this unit and forms angular equant grains showing simple boundaries and even extinction in thin section.

\section{CHLORITE-MUSCOVITE-QUARTZ SCHIST}

The chlorite-muscovite-quartz schist was severely deformed, probably during thrust faulting, and is texturally and structurally distinct from other parts of the carbonaceous metasedimentary sequence. These rocks occur in two klippen, one on the summit and east side of Hill 2592 and the other on a small spur on the east side of Hill 2592. In general, they are greenish gray and weather to very irregularly shaped fragments. Megascopic structures are complex, characterized by lensoid white quartz segregations that are severely contorted and isoclinally folded (fig. 4). They are composed of quartz and muscovite in roughly equal proportions and less abundant chlorite. Minerals present in minor amounts are dusty to granular opaque material, epidote, albite, and tourmaline.

Some quartz is fine grained and irregularly angular to rectangular with simple grain boundaries, but more commonly it is strongly strained and shows complex granulated to sutured grain boundaries. Muscovite is fine to medium grained and occurs in deformed aggregates that outline distorted compositional banding. It is complexly microfolded and has elongate stringers of opaque material along cleavages and grain boundaries. Chlorite is a moderate-grass-green color and is concentrated in layers or in dense aggregates that form sporadically distributed patches. Individual grains within these patches are bent and strained. Small opaque grains of square and rectangular outline occur as inclusions in chlorite.

Of the other minerals present, fine-grained opaque material, probably carbonaceous, is the most abundant. This material commonly is associated with muscovite in thin stringers that sharply outline the complex crenulations resulting from deformation. Albite forms subequant, anhedral grains with irregular boundaries. It is generally above average in size, verging on porphyroblastic. Tourmaline occurs as small rods along the axes of microfolds.

As a whole, this unit is compositionally similar to other parts of the carbonaceous metasedimentary rocks, but texturally and structurally it is much more complexly deformed. Megascopic and microscopic structures vary in complexity, but they clearly reflect at least two episodes of deformation. A strong foliation is parallel to compositional banding defined by varia-

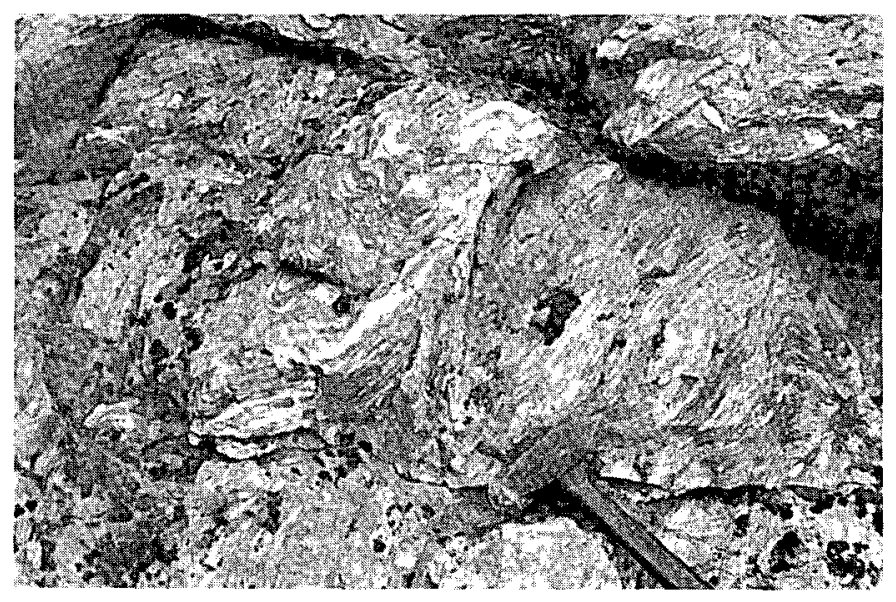

Figure 4.-Outcrop of strongly deformed chlorite-muscovite-quartz schist with complexly folded segregations of white quartz.

tions in chlorite, quartz, and muscovite content. The unit has been intensely crenulated, variously folded, and displaced along axial plane shears (fig. 5).

CARBONATE ROCKS

Carbonate rocks occur as thin interbeds and small lenses as much as about a hundred meters long within the carbonaceous metasedimentary rocks. These carbonate rocks occur throughout the sequence in minor amounts but are most common within mica-quartz schist and similar rocks in the eastern part of the map area. They include calcareous schist and interbeds and lenses of marble that have been mapped separately only in the area north of lower Ferndale Creek.

Marble interbeds are commonly less than $0.6 \mathrm{~m}$ thick, dark gray, fine, to medium grained, carbona-

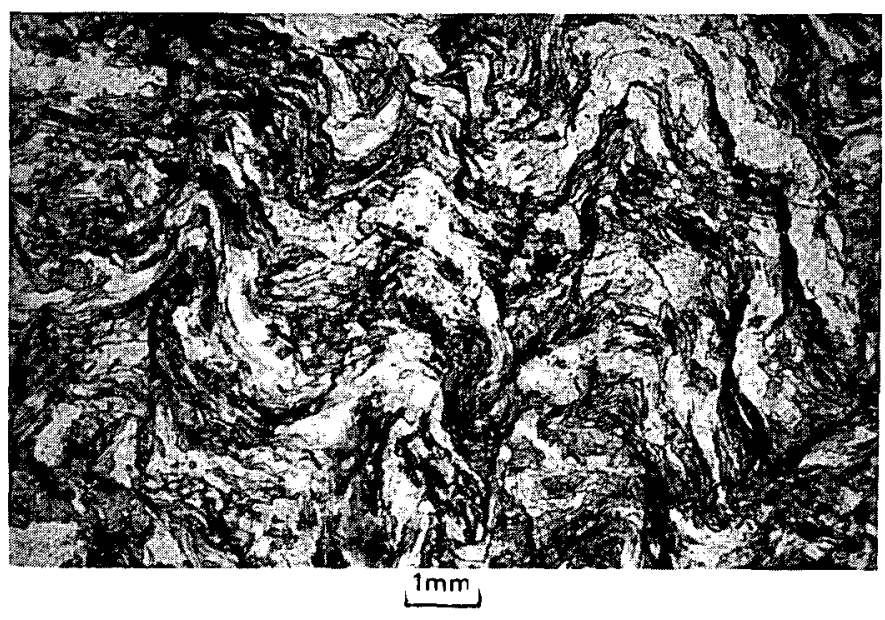

FIGURE 5.-Photomicrographic showing complex deformation features in chlorite-muscovite-quartz schist. Dark dusty and granular opague materials in part outline crenulations. Plane polarized light. 
ceous, and equigranular. The coloration of weathered surfaces is similar to that of fresh surfaces. Weathering does accentuate thinly spaced color banding and some specimens have thin tightly folded quartz bands that stand out conspicuously on weathered surfaces. Less pure micaceous interbeds are medium dark gray to medium gray.

The largest of the marble interbeds occurs in a klippe of chlorite-muscovite-quartz schist $0.6 \mathrm{~km}$ south of Tin Mountain. Here a medium-gray marble band is approximately $3 \mathrm{~m}$ thick, dips in general $5^{\circ}$ to $10^{\circ}$ east, and crops out for more than $0.5 \mathrm{~km}$ in an east-west direction.

Carbonate lenses, commonly less than $30 \mathrm{~m}$ long, are generally medium-gray thinly banded marble with fine cleavage that weathers to platy fragments. Near the granite complex the lenses are recrystallized to more massive splotchy medium-gray variably grained marbles containing coarse white calcite segregations. Impure layers in these thermally metamorphosed rocks have been converted to ruststained brown-green calc-silicate bands that are a combination of diopside, idocrase, plagioclase, calcite, and garnet.

Calcareous schist and associated marble are mapped separately north of lower Ferndale Creek. Here buff-orange-weathering carbonaceous muscovitecalcite schist grades upward into medium-gray semiplaty marble. The relation of these rocks to underlying chlorite-muscovite-quartz schist is not clear, but attitudes of the foliation in closely spaced outcrops of the two schists are nearly the same and the sequence may be entirely transitional.

\section{PALEOZOIC ROCKS}

The Paleozoic rocks of the area are large isolated masses of marble that show complex structural relations to the surrounding metamorphic rocks. These masses occur along the ridge east of Humbolt Creek, where they form barren hills, knobs, and mounds surfaced by frost-riven rubble.

The marble in these masses is fine to medium grained and massive to thinly banded. It is variably colored light and medium gray on fresh surfaces, and it weathers to chunky irregular fragments that are a fairly uniform medium gray in color. The banding is defined by changes in color and is caused primarily by variation in the content of carbonaceous material. Impurities other than carbonaceous material are uncommon.

Small-scale lithologic, textural, and structural variations are common. Calcite may be fine and medium grained in a single specimen, white calcite-cemented marble breccia can be found in some places, and fractures containing iron hydroxides are locally abundant. Individual calcite crystals more than $0.3 \mathrm{~m}$ across and large boulders of milky-white quartz were found in the surface rubble of the northernmost body. Fragments of dark-gray very fine grained schist have been found in surface rubble of the body south of elevation 1808 , and in the mass nearest elevation 1320 , strongly deformed dark carbonaceous calcite schist containing small quartz segregations and veinlets are interbedded and interfolded with massive bufforange-weathering medium-gray fine-grained dolomite.

Abundant remnants of Paleozoic spaghetti corals (probably Silurian or Devonian, according to Charles Merriam, 1973, oral commun.) were found in one of these bodies about $1 \frac{1}{1} 2 \mathrm{~km}$ east of elevation 1320 , near the eastern margin of the map area. Here the marble is massive and variable gray. The coral remnants are white calcite spots and short rods in a much finer grained dark-gray graphitic calcite matrix. These are the only fossils that have been found in the map area; they help identify this and similar isolated carbonate masses as probably different in age from surrounding carbonaceous rocks.

The contact relations of these marble masses to surrounding rocks are complex and generally structural in nature. Imbricate thrust faulting is common in the regional structure of the Seward Peninsula (Sainsbury, 1969b). The restriction of the marbles to higher elevations of the north-south-trending ridge east of Humbolt Creek and their mapped distribution and form suggest that they may be remnants of a once larger thrust sheet that placed them against the carbonaceous rocks. This possibility also is supported by the probable age discrepancy indicated by the fossil corals in some of the marbles, the variability of deformation and recrystallization within the marbles, the complex folding that is evident in the outcrops just east of elevation 1320, and especially the extensive silicification of the marble above the contact with chlorite-muscovite-quartz schist on the west side of elevation 1320 (Sainsbury, 1969b). Normal faulting apparently has downdropped the northernmost thrust remnant and locally formed brecciated zones.

In summary, the larger, isolated marble masses of the area are Paleozoic in age and probably the remnants of a once larger trust sheet. The marble masses differ from carbonate bodies intercalated in the carbonaceous rocks in that they have more uniform weathering characteristics, a more conspicuous variability of small-scale lithologic, textural, and structural features, are less schistose or thinly 
cleaved, contain carbonaceous material as the principal impurity, and tend to be larger.

\section{THERMALLY METAMORPHOSED ROCKS}

The granite complex is sharply discordant and is surrounded by a well-developed thermal aureole of variable thickness that is widest in the southeast part of the map area. Rocks within the aureole have been metamorphosed to hornblende hornfels and albiteepidote hornfels facies (Turner, 1968). A typical mineral assemblage in hornblende-hornfels-facies rocks is quartz-biotite-andalusite-muscovite \pm cordierite and in albite-epidote-hornfels-facies rocks is quartz-biotitechlorite-muscovite. Rocks of albite-epidote hornfels facies have complex textures and mineral assemblages between those of greenschist and of hornblende hornfels facies. In general, incipient thermal metamorphism is indicated by the development of biotite and certain changes in grain boundary relations of quartz.

Biotite is present locally and replaces other micaceous minerals. It is light colored and pleochroic in various shades of tan and yellow. In some samples it has a preferred distribution and is either spatially associated with other mineral grains, such as opaque material, or is concentrated in definite compositional bands. Higher temperature conditions are indicated by darkening of the color to red-brown and by increased grain size. In rocks of higher metamorphic grade, biotite tends to have a bimodal orientation of the cleavage traces both parallel and perpendicular to the trace of the foliation.

Grain boundaries of quartz are another sensitive indicator of thermal gradients in rocks of lower metamorphic grade. Rocks that have not undergone thermally induced recrystallization are characterized by sutured grain boundaries, variable grain size, and undulatory extinction. Upon recrystallization, the quartz grains form granoblastic textures. Incipient recrystallization is evidenced by boundary adjustments that tend to occur in individual zones or domains where quartz is the dominant mineral. Here the initial changes are increases in the length of individual grain boundary segments, a homogenization of grain size, and a decrease in the degree of internal strain. These initial adjustments may be present in rocks having only greenschist-facies mineral assemblages. As metamorphism proceeds, quartz grains throughout the specimen become recrystallized, and granoblastic textures are well developed. These granoblastic textures are unlike those described by Spry (1969) in that the triple points tend to be orthogonal rather than equiangular, probably because of the influence of original bands and layers. In the advanced state of textural adjustments in the siliceous metasedimentary rocks, individual quartz grains are rectangular in outline and form layers one to a few grains thick that are separated by thin, discontinuous, and oriented micarich segregations.

Gradational mineral assemblages between those of greenschist and hornblende-hornfels facies are most obvious in rocks that were originally argillaceous and compositionally inhomogeneous. In these rocks, thermal metamorphism tends to be incomplete, and disequilibrium assemblages and complex textures develop. Disequilibrium assemblages are characterized by mineral compositions that vary and by the coexistence of greenschist- and hornblende-hornfels-facies minerals. Both plagioclase and amphibole (tremoliteactinolite-hornblende) can vary in composition within an individual specimen.

The characteristic minerals of the more extensively recrystallized rocks of the thermal aureole are andalusite and cordierite. Staurolite was found in one thin section of hornfels. Andalusite tends to occur as subhedral porphyroblasts oriented parallel to the foliation. Cordierite occurs dominantly as very irregular elongate poikilitic porphyroblasts that form weblike textures in which oriented inclusions of mica are very abundant.

In summary, the granite complex is surrounded by a distinct thermal aureole in which rocks of hornblende-hornfels facies have been formed. The contact relations and thermally induced mineral assemblages are characteristic of an epizonal plutonic environment, and the temperature gradient between the pluton and the surrounding rocks evidently was steep. The greater horizontal width of the thermal aureole along the southeast margin of the pluton is probably a reflection of the shallow dip of the granite body in that direction.

\section{STRUCTURE}

The structural relations and features discussed in this section occur principally in the metamorphic rocks of the area. The carbonaceous metasedimentary rocks strike north to slightly northeast and have a gentle to moderate dip to the east. Isoclinal overturned folding may have affected parts of the metasedimentary sequence, high-angle faults are abundant in the southeast map area, and thrust faults are possibly present in three areas. The thrust faults are part of the Collier thrust belt (Sainsbury, 1969b), a thrust terrane that includes the entire Seward Peninsula and is characterized by complex imbricate faulting.

Mapping of different lithologic units of the metasedimentary sequence has delineated some high-angle faults, but the question of the importance of large-scale isoclinal folds has not been resolved. 
Such folds are suspected because of the presence of a relatively small overturned anticline, near the southcentral boundary of the map area, that plunges to the south and is several tens of meters in amplitude. This anticline is in fine-grained lineated and banded quartz-calcite-albite-muscovite schist containing some biotite. Apparently similar units of banded hornfels or related rocks are repeated in the south-central map area between the small anticline and the granite contact and may indicate larger isoclinal folding. The stratigraphy is so poorly known that the presence of such folds is conjectural.

\section{FAULTS}

Thrust faulting in three separate areas has been mentioned above in the discussion of the metasedimentary units. These areas are (1) the gneissmetasiltite contact in the north-central map area, (2) the klippen of highly deformed chlorite-muscovitequartz schist and associated marble overlying carbonaceous metasedimentary rocks in the southern part of the map area, and (3) the discontinuous marble masses located along the ridge east of Humbolt Creek.

In the area north of the granite, the principal evidence for thrust faults is the marked discrepancy in metamorphic grade between the metasiltite and gneisses, the absence of features that would characterize a depositional contact between them, and the apparently gentle dip of the mapped gneissmetasiltite contact.

Thrust faulting in the southern map area is indicated by the severe deformation of bodies of chloritequartz-muscovite schist (figs. 4,5 ) and by their map pattern, which suggests that they are thin flatbottomed klippen superimposed on other units of the carbonaceous metasedimentary sequence.

On the ridge east of Humbolt Creek, isolated masses of Palezoic marble overlie the carbonaceous metasedimentary rocks, and a thrust relation is suspected because (1) the mapped distribution of isolated masses indicates that they could have once been part of a continuous sheet, (2) silicification is localized at the base of the marble mass immediately east of the placer workings on Humbolt Creek, (3) dolomitization and complex folding are present in the second mass east of the placer workings on Humbolt Creek, and (4) there is an apparent discrepancy in age between the underlying rocks, believed to be late Precambrian, and the overlying Palezoic marble. Silicification and dolomitization at and near the base of such marble masses is considered by Sainsbury (1969b) to indicate thrust zones in the Collier thrust belt.

High-angle faults are the most widespread and easily recognized structures in the area. Individual faults are identified by topographic discontinuities, linear zones of alteration or deformation, and offset of lithologic units. Where offsets have been recognized, the sense of displacement is normal. These faults are apparently most common in the metasedimentary sequence southeast of the granite complex and near or within the eastern margin of the granite.

Several apparently preferred orientations for the high-angle faults were recognized by Sainsbury, Hudson, Kachadoorian, and Richards (1970, p. H7-H8). The two most conspicuous fault sets trend northeast and northwest. Commonly, fault intersections are at high angles, and the faults define rectangular to irregular fault-bounded blocks. The granite margin is offset in many localities by steep faults, and a relatively large one extends into the interior of the complex, where it terminates as a series of hydrothermally altered splays. The somewhat regularly oriented faults concentrated within the granite complex near its eastern margin are large-scale primary joints along which differential vertical displacements and local offset of the granite contact have occurred. The distribution of high-angle faults in the metamorphic rocks south and east of the granite is important because these structures, particularly those that trend northwest, have localized cassiterite and sulfide mineralization.

\section{AGE OF STRUCTURAL FEATURES}

The relative age of various structures can be determined in part, but the only absolute age reference is a $68-$ to $69-m . y$. K-Ar date for the granite complex. The deformation and metamorphism of the carbonaceous metasedimentary rocks took place before emplacement of the granite complex, and folding within the carbonaceous rocks may have preceded or accompanied thrust faulting. Microfolding in the carbonaceous metasedimentary rocks is common, and as the axial planes are oblique to the primary schistosity, the microfolds may indicate that two periods of deformation affected these rocks. However, much of the microfolding could be related to local tectonic deformation associated with thrust faulting. The thrust faults themselves may have been warped, as suggested by the apparently opposite dips of the gneiss-metasiltite contact north of the granite. The thrusting and possible warping of the thrust sheets predates granite emplacement. The high-angle faults may be of at least three ages. From older to younger these are (1) northeast-trending structures apparently conforming to regional structural trends, (2) northwest- to west-trending structures that displace the granite margin and some thrust sheets, and along which mineralization commonly is localized, and (3) somewhat regularly oriented primary joints near the 
eastern margin of the granite, along which differential vertical movement has occurred but mineralization is not known to be localized.

\section{THE OONATUT GRANITE COMPLEX}

The epizonal stock of biotite granite that dominates the central part of the map area is one of several apparently similar granite plutons that occur in a northeast-trending belt across northern Seward Peninsula (fig. 6). All these plutons are related to tin mineralization and are informally referred to as "tingranites." The granite stock in the Serpentine Hot Springs area is exposed over a large area and to deeper levels than any of the other tin-granites in the belt, and it is therefore best suited of the stocks for the study of the magmatic processes that were operative during their crystallization. The granite stock is here named the Oonatut Granite Complex after the local Eskimo word for the area, which means "place where hot water exists" (C. Weyiounna, written commun., 1974).

The Oonatut Granite Complex is a texturally and compositionally zoned intrusion exposed over an area of about $70 \mathrm{~km}^{2}$, roughly oval in plan except for a bulge in the northeast direction. It is composed mainly of varieties of biotite granite, but leucogranite also is present.

The granite complex is in sharp and discordant contact with adjacent country rocks. In general, the trace of the principal contact is easily identified on aerial photographs or on the ground and overall is continuous and regular. The contact is in many places topographically expressed by changes in surface slopes between bordering country-rock areas and marginal areas within the pluton. These slopes face toward the interior of the pluton and are generally steeper in the

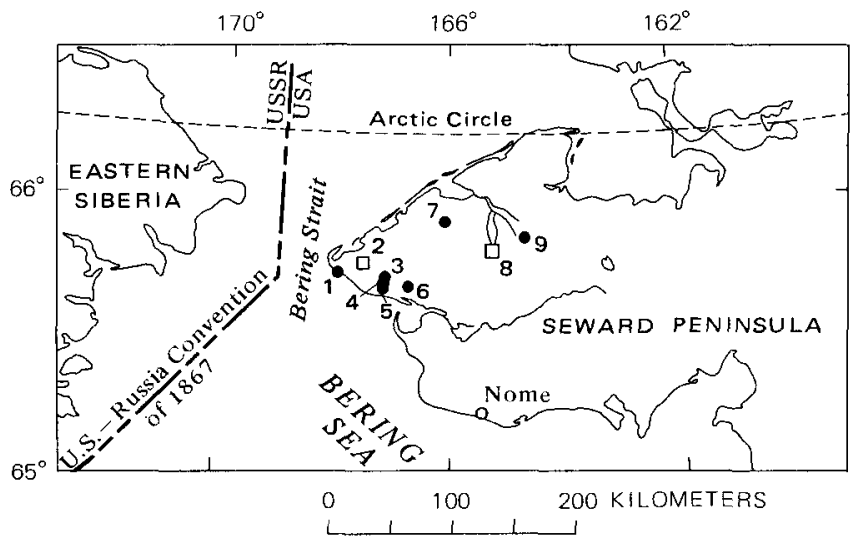

FIGURE 6.-Distribution of tin-granite plutons, northwest Seward Peninsula, Alaska; circles, exposed; squares, inferred at depth. 1-Cape Mtn., 2-Potato Mtn., 3-Brooks Mtn., 4-Lost River Mine, 5-Tin Creek, 6-Black Mtn., 7-Ear Mtn., 8-Kougarok Mtn., and 9-Oonatut Granite Complex (this report). country rocks than in the adjacent parts of the pluton. Rocks of hornblende-hornfels facies are present in the country rocks adjacent to the contact with granite, and their relative resistance to weathering is in large part responsible for their topographic expression. On a local scale, the contact can be very irregular, and diking into the country rocks is common. The dikes, discussed in more detail below, can be as long as $100 \mathrm{~m}$ and in many places are clearly direct offshoots of the granite complex.

A shallow environment for emplacement of the pluton is indicated by the nature of the shiarply discordant contact relations and the presence of many primary voids within the granite complex. The development of rocks of hornblende-hornfels facies within the thermal aureole indicates maximum lithostatic pressures on the order of 2 or $3 \mathrm{kbar}$ (Hietanen, 1967). The presence of many miarolitic cavities in several parts of the pluton, including an open pocket $0.5 \mathrm{~m}$ across, suggests that total confining pressures may well have been less than the maximum pressures indicated by the contact metamorphic mineral assemblages.

The complex is composed of several different textural facies that are part of four principal zones (pl. 1). Some of the facies are texturally and compositionally gradational with one another, but some form distinctly crosscutting intrusions. The field and petrologic characteristics of each zone and textural facies are described below, with emphasis on those parameters that vary from one facies to the next.

\section{MODAL COMPOSITION}

The overall felsic nature of the pluton is illustrated by the modal ratios plotted in figure 7 . The mode for the essential minerals, determined from samples collected from all parts of the complex, is 29 percent plagioclase, 31 percent quartz, 36 percent $K$-feldspar, and 4 percent biotite. Accessory minerals, amounting to less than 1 percent, include apatite, magnetite, zircon, sphene, allanite, and monazite(?). Late-stage or deuteric minerals include muscovite, fluorite, tourmaline, quartz, and albite.

The plot of modal ratios does not directly reveal significant trends in variation in the proportion of the essential minerals. However, preliminary examination of the modal data for the individual textural facies of the complex (described in detail below) suggests that important modal variations are present. The modal proportion of plagioclase appears to increase systematically from facies $1 \mathrm{~B}$ to facies $4 \mathrm{~B}$. In facies $1 \mathrm{~B}$ to 2 , this increase in modal plagioclase corresponds to a decrease in modal quartz content, but in facies $3 \mathrm{~A}$ to $4 \mathrm{~B}$ it is accompanied by shifts to lower $\mathrm{K}$-feldspar and biotite contents. Biotite is most abundant in the intermediate facies (1B-3A), where it 
generally makes up 5 to 6 percent of individual specimens.

\section{PERIPHERAL DIKES}

Granitic dikes in the country rocks surrounding the Oonatut Granite Complex include direct offshoots of the complex, isolated quartz porphyry dikes, and foliated dikes whose relation to the granite complex is not well defined.

Peripheral dikes occur as direct offshoots of the granite complex throughout the area. These dikes are as much as $100 \mathrm{~m}$ long, of differing width but commonly less than $1.5 \mathrm{~m}$ across, and display no systematic orientation. They are very light gray in color, fine grained, and wholly or partly xenomorphic equigranular in texture. Seriate hypidiomorphic textures and relatively abundant graphic and myrmekitic intergrowths are characteristic of some dikes. The essential minerals include quartz and unzoned variably twinned plagioclase in about equal proportions, somewhat less abundant perthitic microcline, and less than 5 percent mica, which is dominantly biotite or muscovite. Accessory minerals are not abundant but locally include a few grains of allanite and more abundant tourmaline. The tourmaline is fine to medium grained and occurs as subhedral intergranular grains, as irregular interstitial grains, and in small vugs. Vugs are common, especially in the more altered specimens. Alteration is the result of oxidation and replacement, locally extensive, by muscovite. Iron

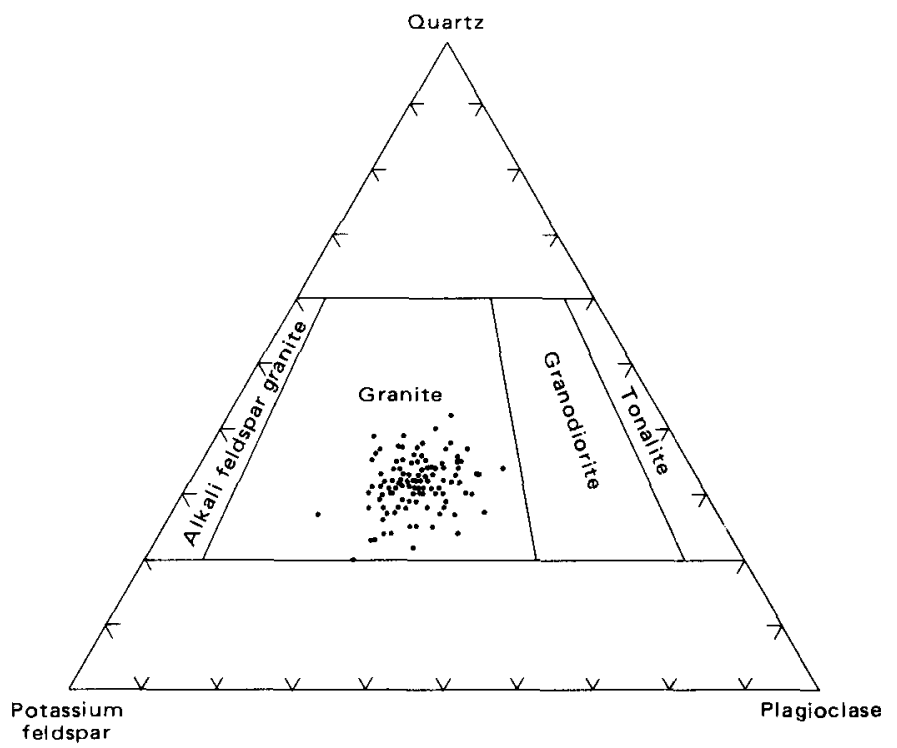

Figure 7.-Plot of modal Pl:Q:Or ratios for samples collected from all parts of Oonatut Granite Complex. Classification scheme shown in diagram follows suggestions of International Union of Geological Science's Subcommission on the Systematics of Igneous Rocks (Geotimes, 1973). hydroxides have caused discoloration and filming of grain boundaries, and biotite has been chloritized.

Quartz porphyry dikes have been found in the peripheral zones of the thermal aureole southeast of the granite complex. These dikes intrude rocks of the carbonaceous metasedimentary sequence, and at the present surface are not connected directly with the granite pluton. They are very fine grained, very light gray to white, and contain rounded-appearing megacrysts of gray quartz, disseminated and commonly oxidized euhedral pyrite, and pervasive fine-grained muscovite. Some specimens contain numerous small vugs that in part display concentrations of mica and secondary iron staining. Some of these dikes are apparently localized along high-angle faults, and at least one of them has been affected by postintrusion faulting (locality C, pl. 1). Soil samples collected along this dike contain anomalous metal values (see table 2).

An area of abundant diking borders part of the northern granite complex and has been identified separately on the geologic map. The dikes here include typical offshoots of the pluton, but more commonly they differ in that they are foliated and oriented in a general north-south direction. This orientation is parallel to the general strike of the metamorphic host rocks, and the dikes may actually be sills.

In general, the foliated dikes are light to medium gray and fine grained. In hand specimen, the foliation is defined by discontinuous segregations of oriented biotite (less commonly muscovite) and strung-out aggregates of quartz. Sugary texture is common, and some gradations between coarser foliated border zones into finer grained sugary interiors have been observed. Some specimens are porphyritic, containing individual plagioclase and perthitic K-feldspar phenocrysts as much as $5 \mathrm{~mm}$ long. In thin section, the foliated dike rocks are dominantly xenomorphic and contain, in decreasing order of abundance, quartz, plagioclase, perthitic K-feldspar, biotite, and muscovite. Chlorite, muscovite, and sericite, all replacing biotite, are common secondary minerals, and oxidized iron produces discoloration.

\section{ZONE 1}

Zone 1 is a discontinuous border zone that was recognized in the field by its characteristic hypidiomorphic nearly equigranular texture and light-gray to white K-feldspar crystals. These characteristics distinguish zone 1 from rocks that are transitional inward from it; zone 2, which is porphyritic and has large pinkish $\mathrm{K}$-feldspar crystals. Within zone 1 the rocks systematically increase in grain size and show important textural shifts inward from the contact. 
These inward changes permit convenient subdivision into three different textural facies. From the contact inward, these facies are referred to as facies $1 \mathrm{~A}, 1 \mathrm{~B}$, and 1C (fig. 8).

$\mathrm{K}$-feldspar changes from small, partly anhedral grains that are generally connected to one another (facies 1A) to those that are slightly above average in grain size, distinctly less interconnected in nature, and showing better defined crystal morphology (facies $1 \mathrm{C}$ ). In this same sequence, quartz changes from equant and generally unconnected grains to partially aggregated clusters of anhedral grains, and thence to well-aggregated clusters of anhedral grains.

FACIES 1A.-MEDIUM-GRAINED EQUIGRANULAR GRANITE

Rocks of facies 1A are medium-grained hypidiomorphic equigranular biotite granite. They are found adjacent to the contact and for a short but unknown distance inwards. They are similar to the peripheral dikes that are direct offshoots of the pluton. The essential minerals occur as individual equant subhedral to anhedral grains that are dominantly $3 \mathrm{~mm}$ in size. Open miarolitic cavities, about $1 \mathrm{~mm}$ across, are common, but in some places the cavities are larger and contain tourmaline, muscovite, and fluorite. Local inhomogeneities are graphic intergrowths, domains a few centimeters across of quartz or feldspar concentration, and a few fine-grained intergrowths of plagioclase, biotite, and minor hornblende. In a few places muscovite extensively replaces some of the facies $1 \mathrm{~A}$ rocks.

Plagioclase displays a wide range of composition $\left(\mathrm{An}_{8}^{-}-\mathrm{An}_{27}\right) . \quad \mathrm{A}$ few scattered apparently unzoned phenocrysts of plagioclase are present in the finest grained parts of this facies. Zoning is uncommon and, where present, is not well developed. The zoned crys-

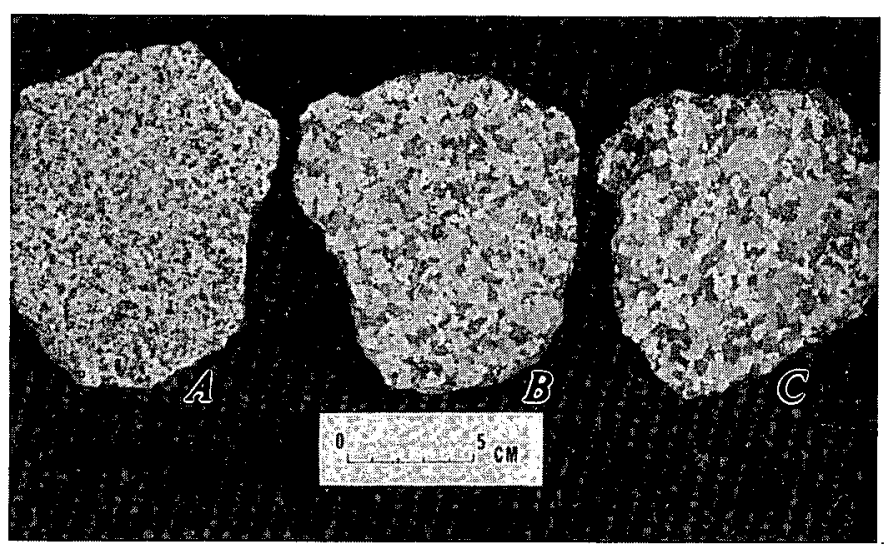

FIGURE 8.-Representative specimens of textural facies in zone 1 $A$, Facies 1A. B, Facies 1B. C. Potassium feldspar in all specimens has been stained and appears gray, plagioclase is white, and quartz is dark gray to black. tals have cores showing even extinction and narrow normally-zoned rims. In a few larger grains, faint oscillations are present in the rims. The composition of the plagioclase is mixed within single specimens as well as between specimens. The zoned crystals and phenocrysts commonly contain more anorthite, but the composition of unzoned crystals cannot be predicted within the overall range of composition.

In thin section, some K-feldspar is euhedral, but most is anhedral, has undulatory extinction and obscure grid twinning, and is microperthite of string or stringlet type. It is characteristically much clouded by minute inclusions of plagioclase, muscovite, and biotite, whereas elsewhere in the complex small muscovite grains are usually the only inclusions. Biotite is fine grained: variable in pleochroism (moderate brown, moderate reddish brown, dark red brown, olive, and dark green brown), and contains abundant pleochroic halos. The accessory minerals include zircon, magnetite, and monazite(?), which occur characteristically as small inclusions in biotite, generally too small for optical identification. A tabular high-relief mineral with high birefringence and inclined extinction may be monazite; it was not found elsewhere in the complex.

\section{FACIES 1B-COARSE-GRAINED APPROXIMATELY EQUI- GRANULAR GRANITE}

The biotite granite of facies $1 \mathrm{~B}$ is transitional inward from that of facies $1 \mathrm{~A}$ and extends to the medial parts of zone 1 . The rocks are characterized by a texture in which linearly seriate anhedral interconnected grains of $\mathrm{K}$-feldspar occur with dominantly equigranular plagioclase and quartz. As a whole the rocks are coarse grained, but the seriate K-feldspar, which is up to $2 \mathrm{~cm}$ across, forms generally larger grains than the quartz and plagioclase form. Quartz is lightto medium-light gray and occurs as clusters and as single subequant grains. Xenoliths(?) of fine-grained plagioclase and biotite, as much as $3 \mathrm{~cm}$ but commonly less than $1 \mathrm{~cm}$ across, are present in more than half of the specimens studied. Other inhomogeneities include small concentrations of quartz and $\mathrm{K}$-feldspar.

Interiors of plagioclase $\left(\mathrm{An}_{\simeq 20}\right)$ grains display patchy extinction, some localized or oriented seriate replacements, and narrow rims normally zoned to albite. Some larger grains have well-developed fine oscillatory zoning but show little overall composition change outward to the rim. Twinning follows combinations of Carlsbad and albite twin laws. The $\mathrm{K}$-feldspar is vein microperthite, commonly grid twinned, and locally has small plagioclase inclusions that outline growth boundaries. Biotite is dark reddish brown and coarser and contains much fewer pleochroic halos ( 1 of every 4 or 5 grains) than biotite 
in facies $1 \mathrm{~A}$. The accessory minerals are intergranular allanite, sphene, magnetite, and zircon. Apatite first appears in this facies, characteristically occurring as oriented small euhedral inclusions in biotite.

FACIES IC-SEMIPORPHYRITIC GRANITE

Biotite granite of facies $1 \mathrm{C}$ is transitional inward from that of facies $1 \mathrm{~B}$ and makes up about one-half of zone 1 . The characteristic texture is one in which subhedral K-feldspar, coarser on the average than other minerals, occurs with coarse-grained plagioclase and quartz; the quartz is anhedral and almost all aggregated into clusters. The $\mathrm{K}$-feldspar is seriate but has a skewed grain-size distribution such that more than half of the grains are larger than the median value in the K-feldspar grain size range. The $\mathrm{K}$-feldspar is significantly less interconnected than that in facies $1 \mathrm{~B}$. Quartz, darker colored than in facies $1 \mathrm{~A}$ and $1 \mathrm{~B}$, commonly is medium light gray. As a whole, plagioclase and quartz form an equigranular subhedral population of average grain size from 0.4 to $0.5 \mathrm{~cm}$. As the median $\mathrm{K}$-feldspar grain size is commonly 1.5 times greater than this, facies $1 \mathrm{C}$ is considered to be semiporphyritic.

In thin section, plagioclase $\left(\mathrm{An}_{19-24}\right)$ grains have distinct central cores with patchy zoning, and marginal normal zoning containing thin and somewhat faint oscillations. The $\mathrm{K}$-feldspar is vein and patch perthite, has well-developed grid twinning, and is marked by growth boundaries defined by both plagioclase inclusions and thin albite lamellae. Biotite and the accessory minerals are similar to those in facies $1 \mathrm{~B}$, except that they are larger grained and more nearly euhedral inwards.

\section{ZONE 2}

Zone 2 is texturally transitional inward from rocks of zone 1. The contact between these zones was identified in the field on the basis of K-feldspar characteristics; zone 2 contains pinkish-gray K-feldspar that is conspicuously coarser grained than other minerals. The transition from typical facies $1 \mathrm{C}$ rocks to those typical of zone 2 is several tens of meters wide. Zone 2 is texturally the most homogeneous in the entire complex and is considered to represent one textural facies, facies 2 (fig. 9).

\section{FACIES 2.-PORPHYRITIC GRANITE}

Typically, the rocks are porphyritic, having large (up to 3 or $4 \mathrm{~cm}$ long) light-pink-gray $\mathrm{K}$-feldspar phenocrysts in a nearly equigranular coarse-grained groundmass of white to very light gray plagioclase and medium-light-gray to medium-gray anhedral quartz all of which is aggregated into clusters. The
$\mathrm{K}$-feldspar is in dominantly euhedral grains at least twice the average size of quartz and plagioclase. There is considerable range in grain size, however, and some specimens contain medium- to fine-grained subhedral to anhedral grains that are in part interstitial. The boundaries of large $\mathrm{K}$-feldspar grains are irregular on a small scale, and the grains have interstitial offshoots and partly include adjacent grains. Preferred orientation of the phenocrysts is common and, combined with the variable aggregation of quartz and plagioclase, produces some local inhomogeneity.

In this section, the plagioclase $\left(\mathrm{An}_{18-26}\right)$ is distinctly zoned. Grain interiors are generally homogeneous, but a few display patchy extinction or marked optical discontinuity with surrounding material. Grain margins with sharp oscillatory zoning are wider than in zone 1. $\mathrm{K}$-feldspar is well-twinned vein and patch perthite with a large proportion of inclusions, mostly of plagioclase but also of quartz and biotite. Included plagioclase generally outlines growth boundaries. Biotite is euhedral, commonly more than $2 \mathrm{~mm}$ across, pleochroic to dark brown, and displays relatively few pleochroic halos. In some specimens biotite shows a preferred distribution, concentrated adjacent to large $\mathrm{K}$-feldspar phenocrysts. Sphene, allanite, zircon, and magnetite are commonly euhedral, intergranular, and coarser grained than in zone 1. Allanite, for example, forms crystals as much as $1.5 \mathrm{~mm}$ long. Magnetite and biotite are more abundant in this facies than in any other.

\section{ZONE 3}

Zone 3 forms most of the central and eastern parts of the pluton and is in sharp concordant to discordant contact with zones 1 and 2 . The contact along the western boundary of zone 3 is concentric with earlier

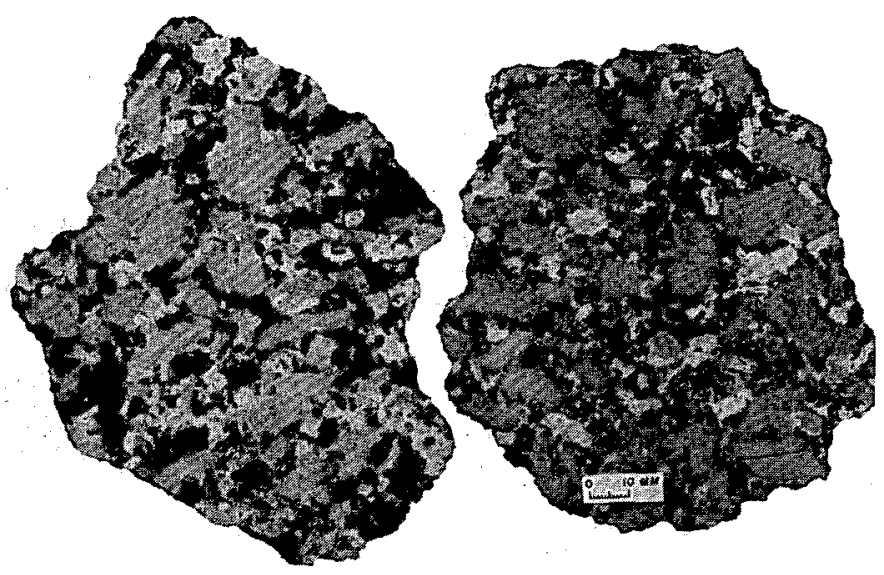

Figure 9.-Representative specimens of zone 2 (textural facies 2). Potassium feldspar phenocrysts in specimen to right are stained and appear gray. Quartz is smoky and appears black. 
zones. This part of the contact is best seen about $90 \mathrm{~m}$ north of the mouth of Center Creek. It is not well exposed, but rocks of zone 2 and zone 3 occur a short distance apart in adjacent outcrops. At this locality, planar mineral segregations trend parallel to the contact and dip $80^{\circ}$ north. The northeastward bulge of the pluton is due primarily to emplacement of parts of zone 3 along the northeast contact. Here zone 3 is discordant to and separates what probably once were continuous parts of zones 1 and 2 . The relations indicate that zone 3 represents a complex intrusion emplaced after crystallization of zones 1 and 2 .

Distinguishing characteristics of zone 3 are variations in texture and structure. As a whole the zone is inhomogeneous, but it characteristically contains large crystals of white K-feldspar (up to $6 \mathrm{~cm} \mathrm{long)}$ that are about half as abundant as K-feldspar phenocrysts in zone 2 . Zone 3 contains two textural facies: $3 \mathrm{~A}$ is seriate, and $3 \mathrm{~B}$ is prophyritic with fine-grained to aplitic groundmass. Facies $3 \mathrm{~A}$ forms pinnacle outcrops and frost-riven rubble in the western and central parts of zone 3 . Common structures in the outcrops include biotite schlieren, coarse feldspar clots and segregations, discontinuous aplite stringers and dikes, pegmatitic pods and dikes, miarolitic cavities lined with euhedral crystals of quartz, albite, and tourmaline, and some larger openings associated with pegmatites. Most of these structures are discussed below. Facies $3 \mathrm{~B}$ occurs predominantly as surface accumulations of frost-riven rubble in areas containing seriate granite and in a large part of the northwestward bulge of the pluton.

The nature of the facies $3 \mathrm{~A}$-facies $3 \mathrm{~B}$ contact cannot be determined in most places, but at one locality (locality D, pl. 1) a sharp intrusive contact of facies 3B against seriate granite is exposed (fig. 10). A large dike of facies $3 \mathrm{~B}$ granite extends about $90 \mathrm{~m}$ into zone 2 at one locality (pl. 1), and most of the discordant contacts between zone 3 and other zones is apparently due to emplacement of rocks typical of facies $3 \mathrm{~B}$.

\section{FACIES $3 A \rightarrow$ SERIATE GRANITE}

Rocks typical of facies $3 \mathrm{~A}$ have an excellent seriate texture (fig. 11). All the essential minerals are seriate, and the euhedral character of these is better developed at larger grain sizes. The larger quartz crystals are doubly terminated, isolated, and have a good basal parting. $\mathrm{K}$-feldspar ranges from small anhedral intergranular grains to large euhedral crystals with boundaries that generally are ragged on a small scale. Plagioclase appears to be subhedral in even the smallest grains.

Some important textural and compositional characteristics of the feldspars correlate with crystal grain

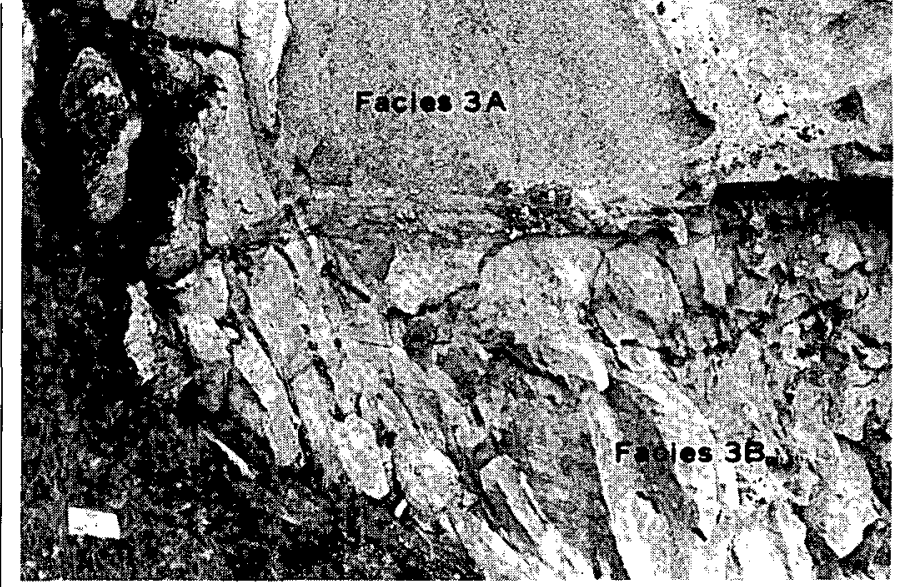

Figure 10.-Exposed contact between facies $3 \mathrm{~A}$ and facies $3 \mathrm{~B}$ located $2.4 \mathrm{~km}$ northeast of Serpentine Hot Springs. Facies $3 B$ at contact is composed of discontinuous very fine grained light and dark bands. Dark bands contain more biotite, magnetite, and flourite. Feldspar-quartz pegmatite is localized at contact at left edge of photograph. Hammer indicates scale.

size and morphology. In thin section, the larger plagioclase crystals $\left(\mathrm{An}_{18-27}\right)$ display zoning that is grossly similar to but better defined than rocks of facies 2, and marginal bands with both oscillatory and normal zoning are wider than in plagioclase crystals of facies 2. The smaller plagioclase crystals lack such well-developed zoning and contain distinctly less anorthite $\left(\mathrm{An}_{11-15}\right)$. The perthitic character and grid twinning of the K-feldspar increase with grain size. Larger crystals are well-developed vein perthites similar to the phenocrysts of zone 2, except that some are a little larger and they are not pinkish. The smaller K-feldspar crystals are not strongly perthitic and lack well-developed grid twinning. Preliminary $\mathrm{X}$-ray studies of large and small K-feldspar crystals show that both are maximum microclines but that there is a slight difference in their albite contents. Two of the large perthites have compositions of $\mathrm{Or}_{95}$ and $\mathrm{Or}_{92}$ and two of the smaller crystals have compositions of $\mathrm{Or}_{97}$ and $\mathrm{Or}_{100}$. As the original compositions of perthites must have been much more albitic, these data suggest that facies $3 \mathrm{~A}$ actually contains four feldspars: (1) larger well-zoned calcic oligoclase, (2) smaller unzoned sodic oligoclase, (3) larger sodic $\mathrm{K}$-feldspar, and (4) smaller soda-free K-feldspar.

Biotite is anhedral to euhedral and pleochroic in shades of amber brown, moderate reddish brown, and reddish brown, in contrast to the general dark-brown coloring of facies 2 biotite. The facies $3 \mathrm{~A}$ biotite has variably abundant pleochroic halos and commonly includes apatite. Allanite, sphene, zircon, and magnetite are all present, dominantly as intergranular grains, and their abundance is variable. 

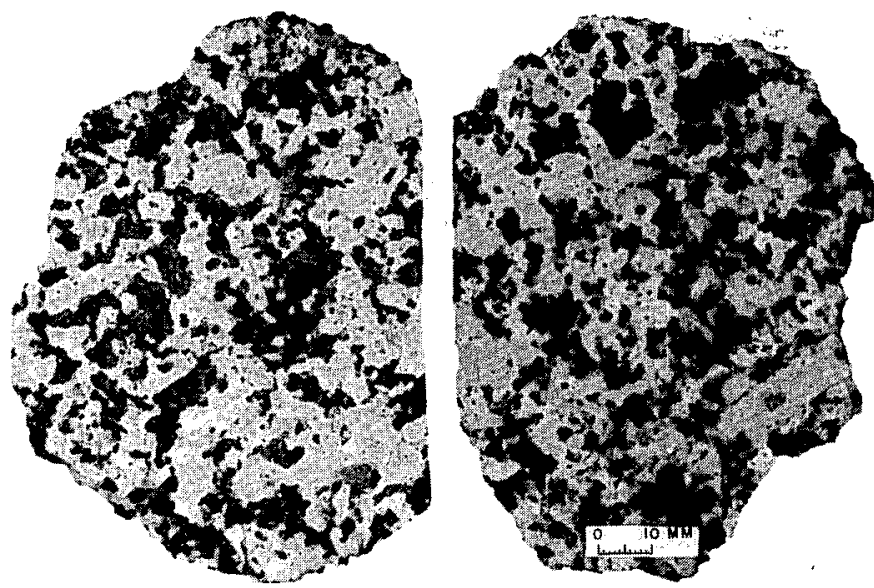

Figure 11.-Representative specimens of textural facies $3 \mathrm{~A}$ Potassium feldspar in right specimen is stained and appears very light gray. Quartz is smoky and appears black.

FACIES 3B-COMPOSITE-TEXT URED GRANITE

Representative examples of facies $3 \mathrm{~B}$ are shown in figure 12. This facies is characterized by $\mathrm{K}$-feldspar, plagioclase, quartz, and biotite phenocrysts in a finegrained to aplitic groundmass of the same minerals. Because of the marked bimodal nature of this texture, it is referred to as composite. The feldspar phenocrysts are subhedral to euhedral. Quartz phenocrysts are equant and subhedral but generally appear rounded in cross section. They are fractured, and some of the fractures appear to be filled by fingers of groundmass $\mathrm{K}$-feldspar. The groundmass forms as much as 80 percent to about 10 percent of the rock. Flow structures and feldspar segregations occur locally within the groundmass. There seems to be a complete gradation in hand specimens between composite and seriate textures. The transitional textures are those in which most of the minerals grade evenly in grain size, but a small proportion is distinctly finer and even-grained aggregates between larger crystals. Because of this relation, the possibility that facies $3 \mathrm{~A}$ is at least locally gradational into facies $3 \mathrm{~B}$ cannot be excluded.

The phenocryst and groundmass mineral populations have distinctly different petrographic characteristics. The plagioclase phenocrysts display variable zoning and have a maximum anorthite content of about $\mathrm{An}_{18}$. Where zoning is well developed, the plagioclase closely resembles that of facies $3 \mathrm{~A}$, but the most distinctive characteristic of plagioclase crystals of facies $3 \mathrm{~B}$ is that many phenocrysts do not show marked internal compositional variations. This is true of large crystals that have well-developed oscillatory zoning, as well as of more typical phenocrysts that only appear to be markedly zoned because of twinning discontinuities or selective secondary mineral replacements, such as sericitic bands or cores replaced

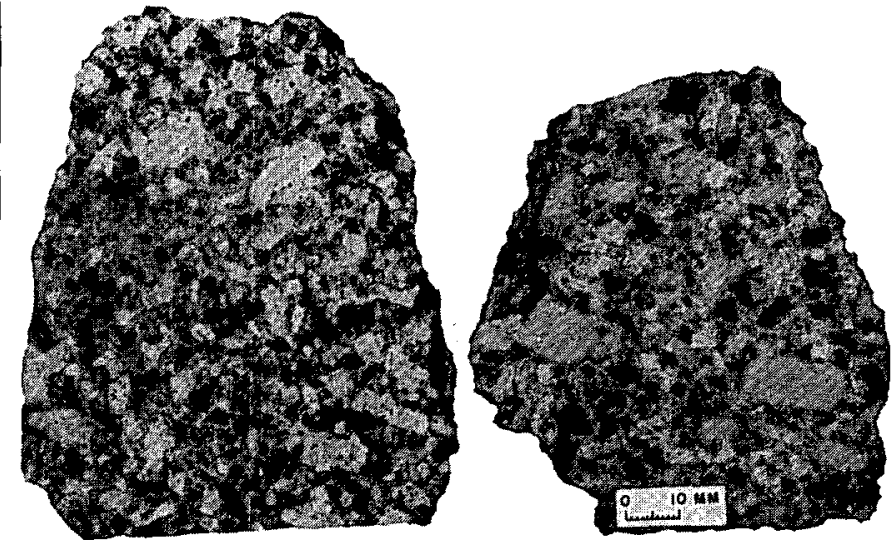

FIGURE 12.-Representative specimens of textural facies 3B. Aplitic groundmass appears gray in left specimen. K-feldspar is stained in right specimen and $\mathbf{K}$-feldspar phenocrysts as well as groundmass appears gray. Quartz is smoky and appears black.

by sericite, clay minerals, or iron hydroxides. The textural contrasts within the phenocrysts, including the apparent or real zoning and also well-developed albitic overgrowths, suggest more compositional variability than is actually present. The textural inhomogeneities appear to be relict features inherited from original crystals that later were compositionally homogenized.

The K-feldspar phenocrysts may be as large as any in the complex, but they are relatively less perthitic and contain fewer inclusions. Individual crystals are string microperthites and vein perthites, have grid twinning, and contain small plagioclase and ovoid quartz inclusions. Overgrowths of nonperthitic $\mathrm{K}$-feldspar are common. Biotite phenocrysts are subhedral to euhedral, dark brown to greenish brown, contain some pleochroic halos, and in addition to apatite commonly include magnetite and some relatively large euhedral zircon crystals. Overall, accessory minerals are less abundant than in facies 2 and $3 \mathrm{~A}$. Magnetite is the most prevalent accessory mineral, being both intergranular and included in biotite, and some well-formed sphene, allanite, and zircon crystals are present.

The groundmass is xenomorphic to hypidiomorphic and equigranular, containing poorly twinned homogeneous plagioclase $\left(\mathrm{An}_{10}\right)$, nontwinned interstitial and partly connected $\mathrm{K}$-feldspar, subsequant quartz, and generally shreddy biotite crystals that commonly are replaced by chlorite and less commonly by muscovite.

ZONE 4

Zone 4 is exposed over an area of less than $1.5 \mathrm{~km}^{2}$ in the central part of the complex. Outcrops are not present in this area; exposures consist of surface accumulations of frost-riven rubble. The zone is 
roughly tear-drop shaped in plan and is topographically expressed along its south end as a small domal hill. It was originally recognized as a separate unit because of the presence of fine-grained equigranular and leucocratic granite not found elsewhere in the complex. Other distinguishing aspects are the dominance of fine-grained xenomorphic to hypidiomorphic equigranular rocks and the occurrence of abundant miarolitic cavities about $1 \mathrm{~mm}$ across, quartz stringers and veins, and some disseminated sulfide minerals. The rocks are transected by several faults along which zones of argillic and related alteration are present.

This zone was studied by examination of thin sections and hand specimens of rocks collected, for the most part, from float along a traverse across its largest dimension. In this traverse, all lithologic variations were sampled. The specimens show that two textural facies predominate and that rocks texturally and compositionally similar to those of facies $3 \mathrm{~A}$ also are present. These last are seriate and subordinate in abundance to those of facies $4 \mathrm{~A}$ and $4 \mathrm{~B}$, both of which are fine to medium grained, xenomorphic to hypidiomorphic and equigranular, but fancies $4 \mathrm{~A}$ is biotite granite and facies $4 \mathrm{~B}$ is leucogranite (fig. 13). Facies $4 \mathrm{~A}$ is widespread in the zone, but facies $4 \mathrm{~B}$ is restricted to areas near hydrothermally altered fault zones. The presence of facies $3 \mathrm{~A}$, largely surrounding this zone as well as scattered through it, suggests that zone 4 may be intrusive into facies $3 \mathrm{~A}$, but the field relations do not clearly reveal the nature of the contacts of zone 4 .

FACIES 4A-FINE- TO MEDIUM-GRAINED EQUIGRANULAR GRANITE

Facies $4 \mathrm{~A}$ is fine to medium grained, xenomorphic to hypidiomorphic, and equigranular, bearing a few scattered megacrysts of feldspar and quartz. The quartz is light gray to medium light gray, and together with biotite ( 2 to 3 percent) imparts a lightgray color to the rocks. Spotty oxidation of biotite, sericitization of plagioclase, and oxidation of disseminated sulfide(?) results in minor buff or cream discolorations. Miarolitic cavities are open, about 1 to $2 \mathrm{~mm}$ across, and appear to make up 1 to 2 percent of individual specimens.

In thin section, most plagioclase crystals in facies $4 \mathrm{~A}$ are not obviously zoned, but a few are. The zoning characteristically consists of distinct cores, defined by selective secondary-mineral replacements and differential extinction, that are surrounded by a faintly normal-zoned rim. Oscillations are locally present but generally are not common. The optical and compositional characteristics of the facies $4 \mathrm{~A}$ plagioclase are similar to those of facies $4 \mathrm{~B}$, except for the presence of the scattered zoned crystals in facies $4 \mathrm{~A}$.

The K-feldspar is dominantly anhedral, has undulatory extinction, is microperthitic in part, and has variably developed grid twinning. In some specimens it is clouded by fine-grained clay(?) minerals. Quartz is interstitial, anhedral, and subequant. Graphic intergrowths are locally well developed. Biotite is reddish brown, subhedral to euhedral, has moderately abundant pleochroic halos, and contains small inclusions of sphene, zircon, and apatite. Generally it is spottily interleaved with chlorite, but replacement is extensive in those specimens in which the K-feldspar is clouded. Accessory minerals are sparse and restricted to the sphene, zircon, and apatite included in biotite.

\section{FACIES 4B-LEUCOCRATIC GRANITE}

Facies $4 \mathrm{~B}$ is the most conspicuous in zone 4 , and it appears to be associated with the hydrothermally altered fault zones. It is characteristically fine grained,
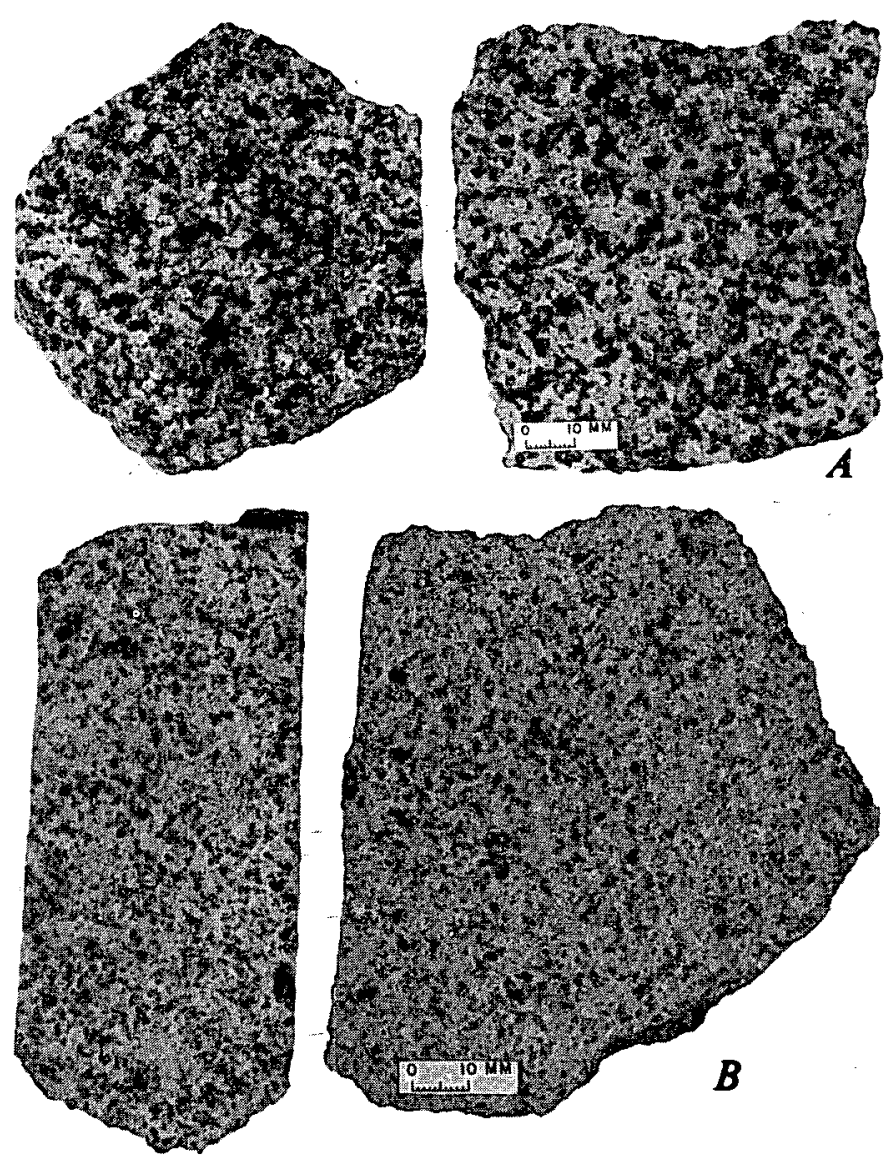

FIGURE 13.-Representative specimens of textural facies in zone 4. Potassium feldspar is stained in right specimens of each and appears light gray. A, Facies 4A. Quartz is smoky and appears black. $B$, Facies 4B. Quartz is light to medium gray and appears medium gray in photograph. 
xenomorphic (except for plagioclase), equigranular, and leucocratic. Fresh surfaces are very light gray because biotite is sparse and quartz is light gray. Buff, spotty iron hydroxide stains, in part associated with miarolitic cavities, are common. The miarolitic cavities are about $1 \mathrm{~mm}$ across, contain small amounts of earthy rust-stained material, and appear to be as abundant as those in facies $4 \mathrm{~A}$. Thin quartz veinlets are common and are discontinuously sheeted and interfingering in places. A few scattered medium-grained megacrysts of quartz and biotite locally are present.

In thin section, the feldspars are partly clouded by clay minerals and contain scattered small grains of muscovite. Plagioclase $\left(\mathrm{An}_{6-15}\right)$ forms short subhedral grains that characteristically have even extinction and are unzoned. K-feldspar is faintly microperthitic, has undulatory extinction, and the grain boundaries range from orthogonal to very irregular and interstitial. Graphic intergrowths are locally present. Quartz forms intergranular anhedral grains and small aggregates. Biotite occurs as remnant grains that have been partly replaced by muscovite. Muscovite also occurs as well-formed intergranular crystals of average grain size. Accessory minerals consist only of very small unidentifiable remnant inclusions in altered biotite, and relatively coarse fluorite. Opaque material is sparse, and most is partially oxidized to bright-orange-red iron hydroxides.

\section{MICROSCOPIC TEXTURES}

Microscopic textures of special interest include those related to subsolidus albite, myrmekite, fringed biotite, and graphic intergrowths. Subsolidus albite, associated myrmekite, and fringed biotite are present in most parts of the complex, but graphic intergrowths are found only in those rocks that can be inferred to have crystallized rapidly and in the presence of a vapor phase.

Subsolidus albite $\left(\mathrm{An}_{<5}\right)$ is characteristically associated with coarser grains of K-feldspar throughout the complex. In addition to lamellae, patches, and veins in perthite, it commonly forms mantles on plagioclase inclusions, marginal rims on intergranular plagioclase, and small discrete interstitial grains that are generally associated with K-feldspar boundaries.

Myrmekite is characteristically associated with subsolidus albite. It consists of very fine grained intergrowths of quartz and recrystallized plagioclase on margins of primary plagioclase crystals, in mantles surrounding plagioclase inclusions in K-feldspar crystals, and in discrete interstitial grains of albite.

Biotite crystals commonly have fringed borders. These fringes are very fine interfingering extensions of the biotite that form a patchy interconnected net- work. Some skeletal biotite crystals occur as small discrete grains not associated with larger biotite plates. The fringes are most obvious at the borders of biotite sections semiparallel to the (001) faces. They are developed along segments of the host biotite border and do not completely surround it. The spotty occurrence and localization at borders of larger crystals suggest that the fringes are the product of late crystallization processes.

Graphic intergrowths occur in plagioclase but are better developed and more common in K-feldspar. They form distinct intergranular grains and marginal bands in feldspar phenocrysts. The intergrowths are found only in rocks that can be inferred to have crystallized relatively rapidly and in the presence of a vapor phase: facies $1 \mathrm{~A}$ (contact-zone rocks), facies $3 \mathrm{~B}$ (porphyritic rocks with fine-grained to aplitic groundmass), and facies $4 \mathrm{~A}$ and $4 \mathrm{~B}$ (fine- to mediumgrained equigranular rocks containing miaroles). In addition, some graphic granite occurs in the interior parts of pegmatitic dikes.

\section{MEGASCOPIC STRUCTURES}

Megascopic structures are abundant, varied in nature, and inhomogeneously distributed in the complex. They include those related to foliations, diking, inclusions, jointing, and cavities. These structures, especially the planar fabrics, are locally very well developed, but efforts toward defining three-dimensional aspects of the complex are handicapped by the lack of outcrops. Many of the structural features are interrelated, but for convenience they are discussed separately below.

\section{FOLIATIONS}

Foliations are defined primarily by mineral segregations, orientation of phenocrysts or inclusions, and tabular swarms of inclusions. Mineral segregations are by far the most important (fig. 14). The segregations include biotite-rich bands, thin discontinuous fine-grained leucocratic zones, and clots and bands of coarse K-feldspar crystals, all of which commonly occur together. The biotite-rich bands generally border the fine-grained zones and coarse K-feldspar segregations. Individual segregations range in thickness from about $2.5 \mathrm{~cm}$ to $10 \mathrm{~cm}$. Large $\mathrm{K}$-feldspar crystals are tabular and show a weak to strong preferred orientation in several parts of the complex. Their orientation generally defines a steep foliation, and in areas where segregations exist they are semiparallel to the foliation defined by the mineral segregations. Inclusions generally take the form of flattened ellipsoids, and their orientation, as well as the orientation of tabular swarms, also defines planar structure in several localities.

Planar fabrics are developed only in zones 2 and 3 of 

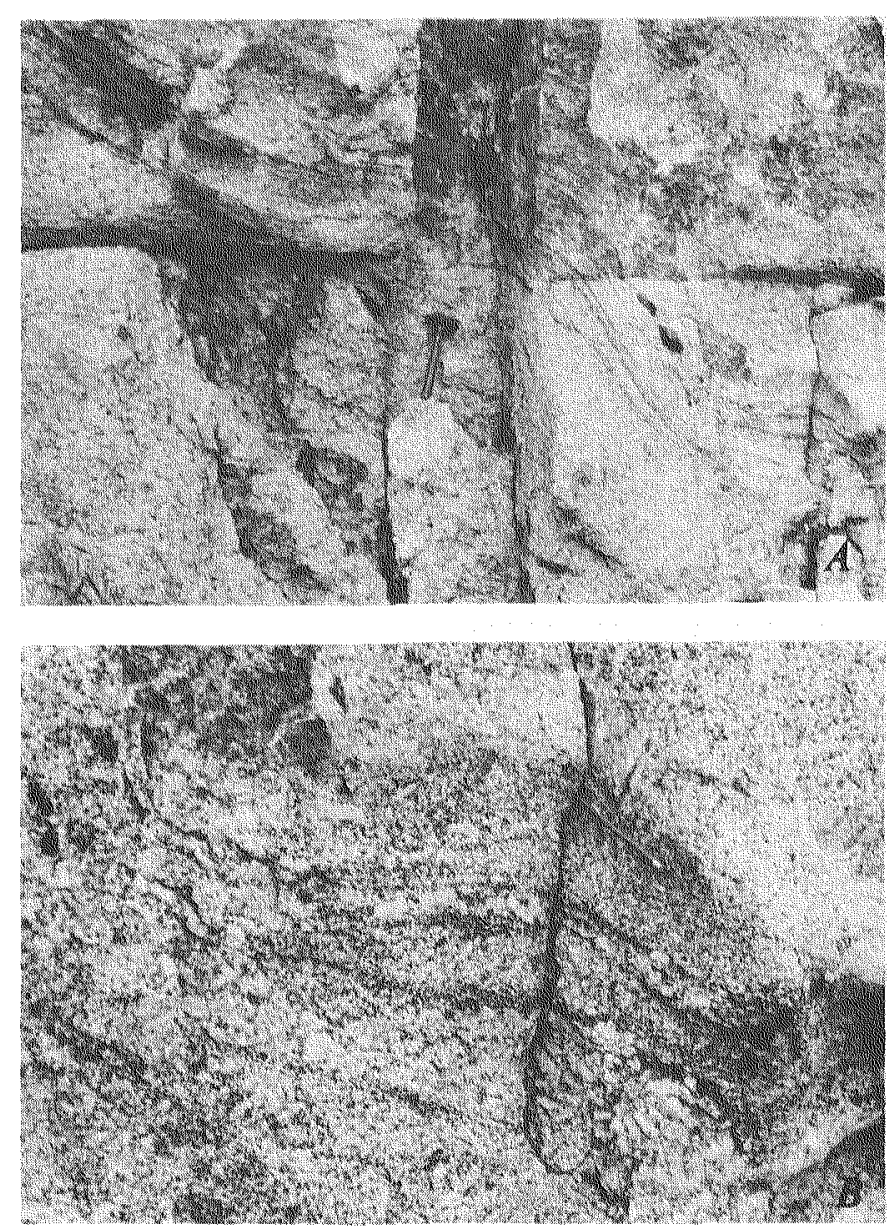

Frgune 14-Mineral segregations in facies 3A. A, Dark biotite-rich bands are separated by lighter colored bands of finegrained granite and clusters of oriented large K-feldspar crystals Dark lensoid xenoliths (right center) are oriented parallel to segregation bands. $B$, Close-up of figure $14 A$ (center) showing biotite-rich bands.

the complex. In zone 2, K-feldspar phenocrysts are locally alined, and the best developed swarms of inclusions are present. In zone 3 , the seriate-textured facies (3A) contains schlierenlike mineral segregations, and in the composite-textured facies (3B), alinement of K-feldspar phenocrysts and some flow structures within the aplitic groundmass are present in hand specimens.

\section{DIKES}

Porphyritic, aplitic, and aplitempegmatite dikes are present in the complex. They are all of granite composition and represent segregations of residual materials within mostly crystallized parts of the pluton or distinct intrusions of such materials into previously crystallized zones. Most are less than $0.6 \mathrm{~m}$ wide.

The porphyritic dikes contain phenocrysts of biotite, quartz, K-feldspar, and plagioclase in an aplitic groundmass. Only two such dikes have been located. One is a foliated dike 5 to $12 \mathrm{~cm}$ thick, at an elevation of $240 \mathrm{~m}$ in zone $2,1.6 \mathrm{~km}$ south of Serpentine Hot Springs. The other is a direct offshoot, about $90 \mathrm{~m}$ long, of the main intrusive body of facies $3 \mathrm{~B}$ into zone 2 at a point on its northern contact with zone 3 (pl. 1). These represent distinct intrusions of partly crystallized materials into previously crystallized parts of zone 2.

Aplite dikes, commonly less than $8 \mathrm{~cm}$ thick, are by far the most widespread and abundant and are present in both zones 2 and 3 . In zone 2 , they are the most common dikes and occur in subparallel groups of two or three. They are more abundant in zone 3 , but there they are discontinuous and branching (fig. 15).

Composite aplite-pegmatite dikes are restricted to facies $3 \mathrm{~A}$, except for a few in zone 2 . They are texturally and compositionally zoned. Aplite typically forms the major part of each dike, and it borders the more centrally located pegmatite. The pegmatite contains coarse $\mathbb{K}$-feldspar, plagioclase, quartz, and in places tourmaline and muscovite. Compositional inhomogeneity is defined by variations in the distribution of feldspar and, to a certain extent, of quartz. Coarse K-feldspar has preferentially crystallized at the stratigraphic roof of the pegmatite zone, and in some thicker dikes it actually forms graphic crystals, as much as $20 \mathrm{~cm}$ long, that extend downward into central parts of the zone. The K-feldspar concentration is accompanied by quartz, and plagioclase in turn has crystallized at the bottom of the zone and is commonly finer grained than the K-feldspar.

Some of the thicker dikes, for the most part aplitepegmatite dikes, have many alternating mineral segregation bands parallel to, but not symmetrically distributed about, them (fig. 16). Fine-grained and aplitic granite within a zone of mineral segregation becomes more clearly defined updip, where a pegmatite pod is present in the central part of an aplite dike.

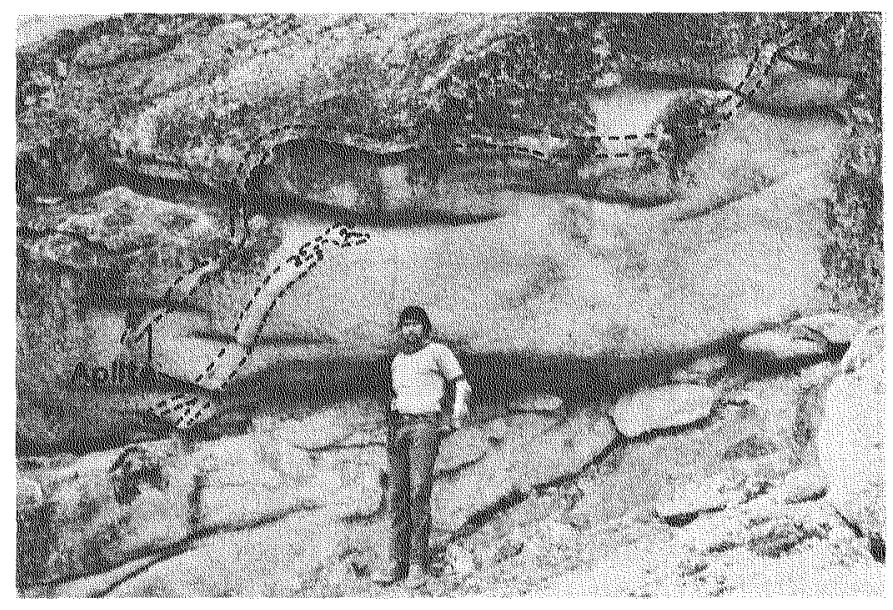

Froure 15.-Discontinuous and branching aplite dikes in facies 3A. Thicker parts of dikes form ridges on weathered and partly lichen-covered outcrop surface. 

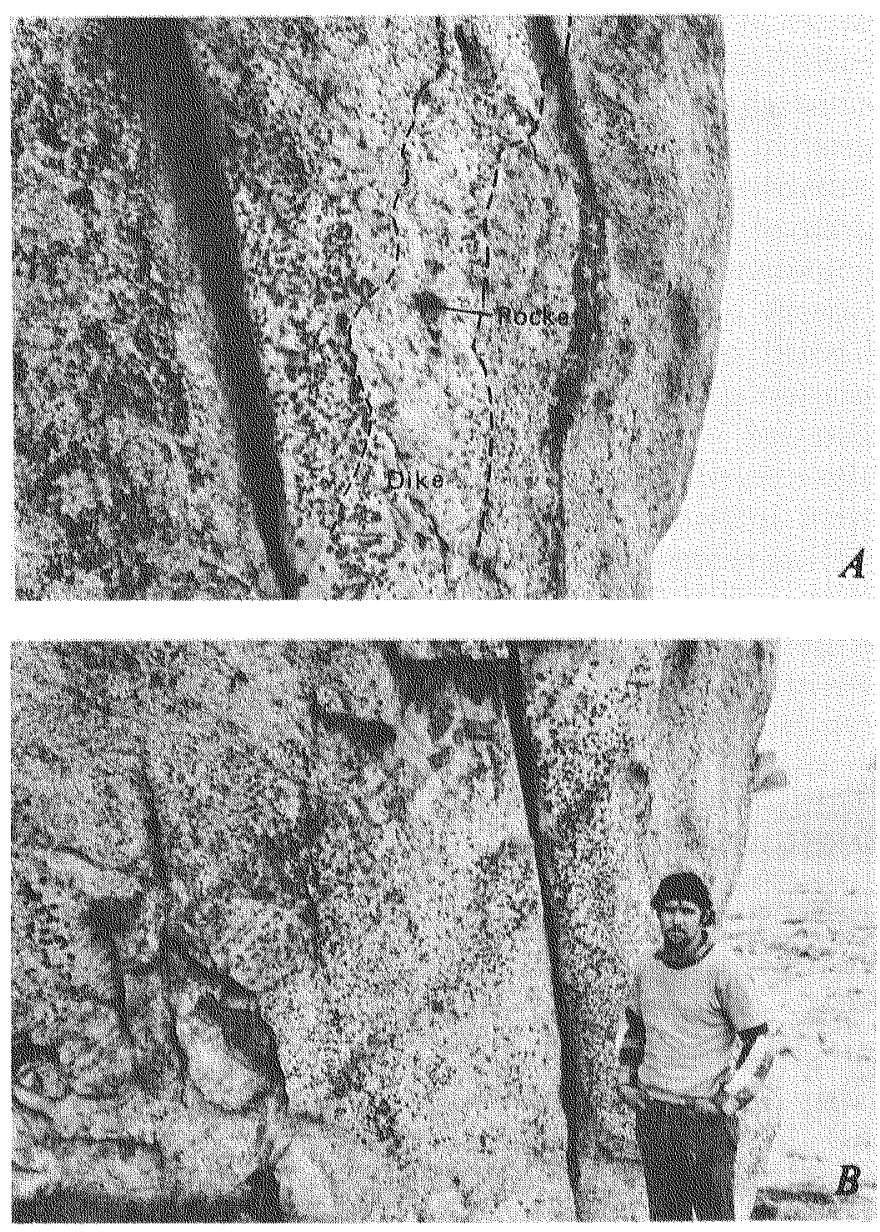

Frcuns 16.-Wike in facies $3 \mathrm{~A}$ grades downdip over a vertical distance of about $8 \mathrm{~m}$ into banded granite zone. $A$. Composite 1m wide aplite-pegmatite dike. $B$, Banded fine-grained granite zone.

The aplite-pegmatite dikes in facies $3 \mathrm{~A}$ are believed to be the result of segregation, by which residual melts and volatiles were concentrated into discontinuous dikelike bodies within the almost completely crystallized parent rocks. Probably all variations from the hazy and thin mineral segregations, such as those il lustrated in figure 17, to the well-defined meter"thick aplite-pegmatite dike of figure 16 are present in facies $3 \mathrm{~A}$.

There is one known example of a pegmatite pod within seriatemtextured rocks in facies $3 \mathrm{~A}$ (fig. 17). This body contains a lower aplite and an upper coarse quartz-feldspar intergrowth with some vugs containing euhedral tourmaline and quartz. The aplite is in sharp contact with the host rocks, but the coarse intergrowth is separated from the seriate granite by a thin zone of equigranular material.

\section{CAVITTES}

Three principal types of cavities occur within the granite complex: (1) miarolitic cavities that contain late-crystallizing minerals, (2) larger openings (pock-

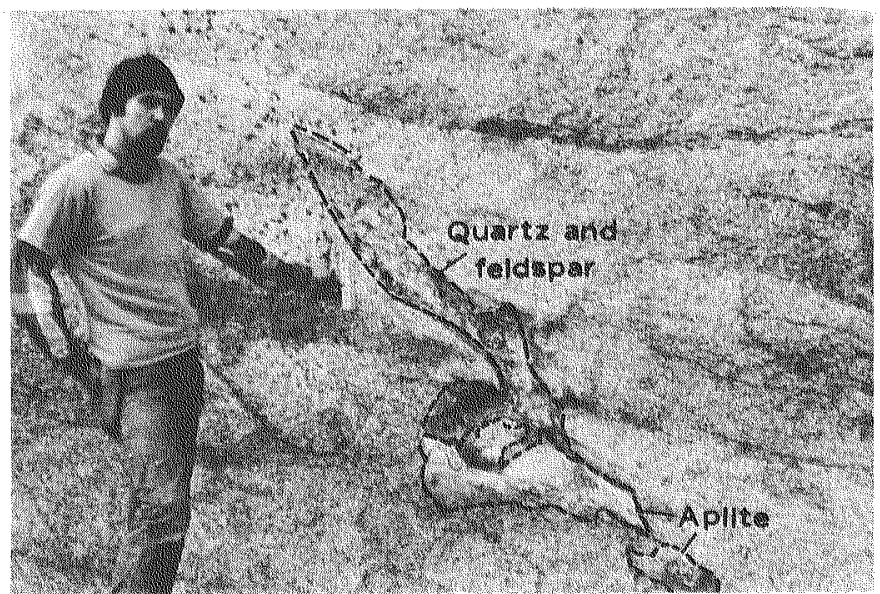

Ftgure 17.-Quartz-feldspar pegmatitic pod in facies 3A. Aplite segregation forms lower part of pod.

ets) in or near pegmatitic bodies, and (3) small miarolitic cavities that are generally open voids free of latewcrystallizing minerals.

The miarolitic cavities that contain late-crys. tallizing minerals are found in the seriate-textured rocks (facies $3 \mathrm{~A}$ ) of zone 3 . The cavities are irregular openings as much as $2 \mathrm{~cm}$ across containing euhedral crystals of smoky quartz, cleavelandite, muscovite, tourmaline, and flourite (in order of decreasing abundance). The cavities are associated with large $\mathrm{K}$-feldspar crystals and clots of such crystals. Characteristically smaller cavities are located immediately adjacent to the large crystals. They are rust stained, and an earthy buff-brown material commonly coats the euhedral minerals that project into the voids.

The pockets are also associated with seriatetextured rocks of facies $3 \mathrm{~A}$ and mostly form openings as much as $5 \mathrm{~cm}$ across in pegmatitic dikes and pods, but one is an open void $0.5 \mathrm{~m}$ across wholly within seriate-textured rocks. The pockets in pegmatitic rocks contain euhedral minerals as in the case of the miarolitic cavities described above, the principal difference being primarily one of size. The walls of the $0.5-\mathrm{m}$-wide pocket (locality $\mathrm{D}, \mathrm{pl}, 1$ ) contain a vuggy equigranular crust of euhedral cleavelandite, muscom vite, quartz, tourmaline, flourite, and a trace of ilmenite that replaces the seriate textured granite, in a selvage about $8 \mathrm{~cm}$ wide (fig. 18). Pseudomorphs of muscovite and albite after K-feldspar phenocrysts can be identified in the selvage. This pocket is found near a massive quartz-feldspar pegmatite at a contact where facies $3 \mathrm{~B}$ intrudes facies $3 \mathrm{~A}$ (fig. 10). Continuity between the pegmatite and the pocket $8 \mathrm{~m}$ distant (as now exposed) is probable but cannot be dem. onstrated because of the lack of exposure.

The third type of cavity is small miarolitic cavities, up to $2 \mathrm{~mm}$ across, that are abundant in the equim 


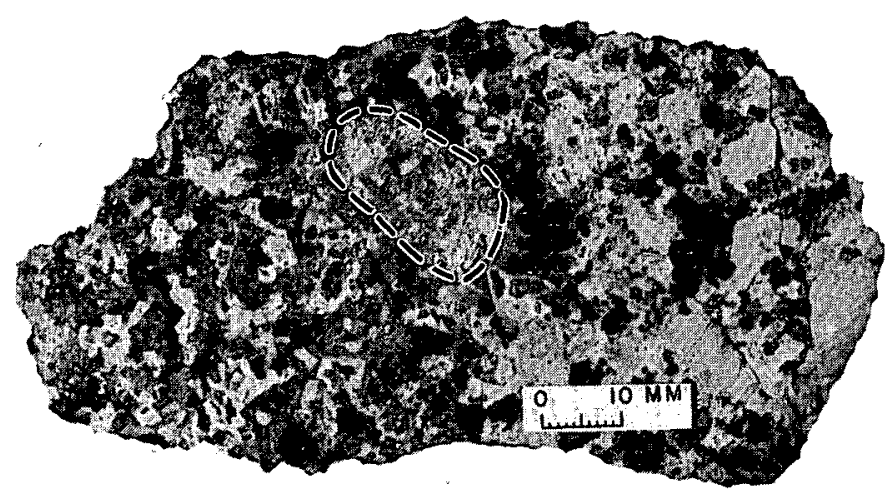

Figure 18. - Vuggy replacement selvage (left side) developed along walls of $0.5-\mathrm{m}$-wide pocket in facies $3 \mathrm{~A}$ (right side). Selvage is composed of roughly equal amounts of euhedral muscovite and albite and lesser amounts of flourite, tourmaline, and rutile. Albite-muscovite replacement of large potassium feldspar crystal indicated by dashed line. Pocket containing replacement selvage is exposed along a separated joint plane about $8 \mathrm{~m}$ to left of photograph shown in figure 10 .

granular rocks of zone 4 . No late-crystallizing minerals were observed in the small cavities, but some were rust stained. Interstitial fluorite and muscovite were seen in thin sections of some rocks of zone 4 , however, and these minerals might occur in some of the small cavities. The cavities are estimated to compose 1 to 2 percent of the volume of the host rocks. Evidently, more interstitial aqueous fluid was present in zone 4 than anywhere else in the pluton.

As discussed above, openings are generally associated with rocks of zone 3 and zone 4 . However, there are no voids within the composite-textured rocks of facies 3B. A few miarolitic cavities containing euhedral minerals occur in dikes in country rocks and in rocks of zone 1 (facies $1 \mathrm{~A}$ ) very near the granitecountry rock contact.

\section{INCLUSIONS}

Two principal types of inclusions are present in the granite complex. One type is fine to medium grained, dark gray, and contains a few megacrysts of quartz, plagioclase, and pink K-feldspar. The other is brownish gray and has a porphyritic texture with coarse megacrysts of quartz, placioclase, and pink K-feldspar in a fine-grained aggregate of the same minerals, together with biotite. Inclusions of the first type may be true xenoliths, but the others are autoliths.

Common to both types of inclusions are finer grained anhedral microcline and equant quartz, brown biotite, and fine-grained plagioclase with characteristically smoothed crystal edges. The darker, finer grained inclusions contain more biotite, disseminated acicular apatite, and green hornblende (up to 5 percent). In these, the microscopic textures include interlocking aggregates of small anhedral grains, net- works of skeletal inclusion-riddled quartz grains, and radiating clusters of plagioclase laths. In the inclusions characterized by porphyritic texture, the finer grained material forms an interlocking aggregate of subhedral grains similar to that in many darker finegrained inclusions, but it contains relatively more abundant microcline, and sphene and allanite as accessory minerals. The megacrysts are generally well formed but somewhat rounded. Reaction rims are present on plagioclase crystals, and some K-feldspar is mantled by thin bands of plagioclase. Large plagioclase crystals have faint oscillatory zoning, large distinct interiors showing homogeneous extinction and well-developed albite twinning, and thin reaction rims that locally contain minute inclusions and differ slightly in extinction and twinning from interior areas. K-feldspar megacrysts are perthitic, with irregular margins and partially albitized plagioclase inclusions. Coarser biotite grains form some megacrysts and contain magnetite and zircon inclusions. The finer grained biotite is generally free of inclusions.

The inclusions commonly are irregular flattened ellipsoids $25 \mathrm{~cm}$ or less in maximum dimension, a very few are angular, and some are tabular and up to $1 \mathrm{~m}$ long. Where planar structures, such as schieren, are present, the inclusions are alined with them (fig. 17). They can be isolated or occur in groups that range from a few scattered in a small area to dense pipelike or tabular swarms that can be a few meters wide and tens of meters long. In the groups, both principal types are found together, though one can predominate over the other.

The inclusions are exposed in outcrops of both zones 2 and 3 , but they are most abundant in zone 2 . Zone 2 contains the dense swarms as well as the numerous small clots, less than $2 \mathrm{~cm}$ long, of fine-grained plagioclase, biotite, and lesser green hornblende that are present in more than half of the hand specimens examined.

\section{JOINTS}

Joints are present in all large outcrops, and the forms of outcrops are determined by the orientation and spacing of the joints because of preferential weathering along them. They are best developed in zone 2 but also are present in parts of zone 1 and zone 3 . They are systematically oriented but are variably spaced, and three sets usually can be recognized in individual outcrops. Two particularly strong sets intersect at nearly a right angle. One trends about N. $65^{\circ} \mathrm{E}$. and is steeply dipping, and the other trends N. $37^{\circ} \mathrm{W}$. and dips moderately to the northeast in central areas but is less systematically oriented and steeper in marginal areas.

Joints crosscut late intrusive units, such as aplite 
and pegmatite dikes and small porphyritic plugs. They also transect dark inclusions. In many places, dikes strike parallel to one of the joint sets but dip in an opposite direction. Locally (especially in zone 2), some fracture systems containing late muscovite, quartz, tourmaline, and fluorite are parallel to one of the clearly recognized joint sets, and the late minerals appear to have healed them. In the eastern part of the pluton where zone 1 is present, much differential movement has occurred along parallel sets of throughgoing joints(?) that in part appear to extend into country rocks. They are evidenced by linear topographic expressions, the presence of slickensided and polished granite fragments, and zones of iron hydroxide staining due to oxidation. Although oxidation appears to have been localized along these fractures, they have not been mineralized and are mapped as fault zones on plate 1 .

\section{DEUTERIC FEATURES}

Products of deuteric crystallization are present in minor amounts in all the textural facies of the complex. They include materials related to the alteration of biotite and feldspar and to precipitation in interstitial voids. The character of the deuteric crystallization changes through the facies sequence, and it locally merges with hydrothermal alteration in facies $1 \mathrm{~A}$ and $4 \mathrm{~B}$.

In the facies of zone 1 , the principal deuteric product is muscovite. It forms interstitial grains, abundant scattered inclusions in plagioclase, and small grains that are adjacent to or interleaved with biotite. The biotite is commonly preferentially replaced along the cleavages by a pale-green chlorite that shows gray interference colors. Deuteric crystallization locally merges with hydrothermal alteration in facies $1 \mathrm{~A}$, where sericite is common in plagioclase, K-feldspar is very clouded by minute inclusions that are probably clay minerals, flourite is associated with late-forming muscovite, and schorl is present in many cavities.

In zone 2 , deuteric crystallization is characterized by grass-green chlorite (with blue-gray interference colors) that replaces biotite along cleavages and in patches. Some of the biotite is a bright red brown near chloritized areas. Other late-stage products are restricted to scattered muscovite crystals in parts of some plagioclase grains.

In zone 3 , the seriate-textured rocks (facies $3 \mathrm{~A}$ ) characteristically contain much deuteric muscovite that forms interstitial grains, as well as patchy crystals in altered plagioclase, particularly in the interiors of zoned crystals. It is generally accompanied by small anhedral disseminated interstitial grains of fluorite. Grass-green chlorite with blue-gray interfer- ence colors patchily replaces some biotite that is in part similar to altered biotite in zone 2 . In compositetextured rocks (facies 3B), the groundmass crystals are characteristically more altered than the phenocrysts. Small shreddy grains of biotite are partly to completely replaced by pale- to deep-green chlorite, and muscovite is relatively common as intergranular to interstitial grains and as crystals attached to the margins of larger biotite grains. Interstitial anhedral fluorite is relatively common, and feldspars are variably clouded by minute inclusions.

In zone 4, the effects of deuteric crystallization locally merge with those of hydrothermal alteration. In facies $4 \mathrm{~A}$, bright-red-brown partly oxidized biotite is interleaved with muscovite. Muscovite also occurs intergranularly and as replacements in plagioclase. Interstitial fluorite is common and some interstitial tourmaline is present, but chlorite is absent. In facies 4B, muscovite occurs as somewhat shreddy intergranular grains, and interstitial fluorite is common. The shreddy muscovite has thin inclusions of opaque minerals and sphene oriented along the cleavages, as well as discontinuous shreds that are pleochroic in shades of brown, which indicates that muscovite replaces biotite crystals. The altered nature of the feldspars in facies $4 \mathrm{~B}$ varies considerably. In some specimens both plagioclase and K-feldspar are extensively clouded by minute inclusions, and in others plagioclase has been preferentially replaced. Yet there are specimens of facies $4 \mathrm{~B}$ in which neither feldspar shows signs of late-stage alteration. Probably there is a complete gradation from rocks of facies $4 \mathrm{~B}$ that contain unaltered feldspars, quartz veins, bleached quartz, and muscovite after biotite to the extensively argillized and silicified rocks present in the hydrothermally altered fault zones that cut zone 4 .

In summary, muscovite, chlorite, and clay minerals are the dominant late-stage products of deuteric crystallization. These minerals are accompanied by interstitial anhedral flourite and locally by tourmaline. Both facies $1 \mathrm{~A}$ and facies $4 \mathrm{~B}$ show evidence of extensive late-stage changes that appear to merge with those of hydrothermal alteration. These changes involve locally extensive replacement of feldspars by sericite-muscovite and clay minerals and replacement of biotite by muscovite. In the facies $1 \mathrm{~B}-1 \mathrm{C}-2$ transition, the principal deuteric product is chlorite. The chlorite replaces biotite and becomes darker green and more anomalous in interference colors inward through this part of the facies sequence. Chlorite similar to that in facies 2 is present in facies $3 \mathrm{~A}$, but the latter contains more muscovite and fluorite than facies 2 . The groundmass of facies $3 \mathrm{~B}$ contains very few unchloritized biotite grains, and muscovite, flou- 
rite, and clay(?) minerals are all relatively abundant. Deuteric crystallization in zone 4 is locally complex, but overall it is characterized by the presence of muscovite and the absence of chlorite.

\section{SUMMARY OF PETROLOGIC RELATIONS}

The Oonatut Granite Complex is an epizonal composite biotite granite stock consisting of four partly concentric zones. Zone 1 is a discontinuous border of equigranular biotite granite that grades inward by increasing grain size, increasing aggregation of anhedral quartz, and increasing morphological development of $\mathrm{K}$-feldspar to zone 2 . Zone 2 is porphyritic biotite granite characterized by large well-formed pinkishgray $\mathrm{K}$-feldspar phenocrysts in a coarse-grained equigranular groundmass of plagioclase, quartz, and biotite. Zone 3 is in sharp and partly discordant contact with zones 1 and 2 . Zone 3 contains seriate fine- to coarse-grained biotite granite and intrusive bodies of composite-textured biotite granite. The compositetextured biotite granite contains abundant phenocrysts of plagioclase, quartz, K-feldspar, and biotite in an interstitial fine-grained to aplitic groundmass. It forms most of the northeasterly bulge in the pluton margin. Zone 4 is a small area in the center of the complex containing fine- to medium-grained equigranular biotite granite and minor leucogranite that is spatially associated with hydorthermally altered fault zones. Well-developed mineral segregations, pegmatite and aplite segregations, and miarolitic cavities containing tourmaline, cleavelandite, quartz, and muscovite are present in seriate biotite granite of zone 3. Small cavities free of late-crystallizing minerals are abundant in zone 4 .

The field and petrologic data suggest that the crystallization history of the Oonatut Granite Complex included three stages: (1) an initial stage that involved inplace crystallization of the marginal facies of zones 1 and 2, (2) an intermediate stage in which interior magma was displaced and crystallized to form the seriate biotite granite of zone 3 , and (3) a final stage that involved emplacement of residual crystal-rich magma to form the composite-textured biotite granite and crystallization of a relatively small volume of water-rich magma in the interior of the complex to form equigranular biotite granite of zone 4. Highangle faulting appears to have displaced the crystallized walls of the complex during the final crystallization stage and may have led to rapid crystallization of zone 4 biotite granite by allowing immediate escape of a coexisting vapor phase. Subsequent low-temperature reaction of remnant vapor and crystallized granite in the roots of the fault zone produced hydrothermally altered rocks, including the leucogranite of zone 4 .
AGE

A Late Cretaceous age is assigned to the Oonatut Granite Complex on the basis of two K-Ar radiometric age determinations of about 67 and $69 \mathrm{~m} . \mathrm{y}$. provided by Marvin A. Lanphere of the U.S. Geological Survey on biotite separates from samples representative of facies 1C (69AH228) and facies 2B (69AH283). The analytical data are shown in table 1 . These dates help to substantiate correlations with other bodies of biotite granite to the west (Collier and others, 1908; Sainsbury and others, 1968), one of which also has been dated by the K-Ar method and found to be about 75 m.y. old (Sainsbury, 1969a, p. 61).

TABLE 1.-Analytical data for $K$-Ar age determinations

Argon analyses and age calculations by J. C. Von Essen; potassium analyses by L. B. year ${ }^{-1}$; atomic abundance of $\mathrm{K}^{40}=1.19 \times 10^{-4}$

\begin{tabular}{|c|c|c|c|c|c|c|}
\hline $\begin{array}{l}\text { Field } \\
\text { No. }\end{array}$ & Mineral & $\frac{\text { Location }}{\text { Lat (N.) Long (W.) }}$ & $\begin{array}{c}\text { Percent } \\
\mathrm{K}_{2} \mathrm{O}\end{array}$ & $\begin{array}{l}\mathrm{Ar}^{4(1)} \mathrm{rad} \\
(\mathrm{moles} / \mathrm{g})\end{array}$ & $\frac{\mathrm{Ar}^{40} \mathrm{rad}}{\mathrm{Ar^{40 }} \text { total }}$ & $\begin{array}{l}\text { Apparent } \\
\text { age (mil- } \\
\text { lions of } \\
\text { years) }\end{array}$ \\
\hline $69 \mathrm{AH} 228$ & Biotite -.. & $\begin{array}{c}65^{\circ} 50^{\prime} 164^{\circ} 35^{\prime} \\
\text { (Zone 1) }\end{array}$ & 8.495 & $8.624 \times 10^{-10}$ & 0.90 & $67.5 \pm 2$ \\
\hline $69 \mathrm{AH} 283$ & .. do & $\begin{array}{c}65^{\circ} 51^{\prime} 164^{\circ} 42^{\prime} \\
\text { (Zone 2) }\end{array}$ & 9.155 & $9.563 \times 10^{-10}$ & 0.90 & $69.4 \pm 2$ \\
\hline
\end{tabular}

\section{ECONOMIC GEOLOGY}

The Serpentine Hot Springs area includes placer deposits of gold and cassiterite and several bedrock areas with anomalous concentrations of base metals, silver, and tin. The presence of cassiterite in placers was first reported by Collier (1904b, p. 28) and later confirmed by Knopf (1908ba, p. 63). Moxham and West (1953) outlined the occurrence of mineralization, lode prospects, and placer deposits in the Serpentine-Kougarok area and summarized the results of investigations for radioactive minerals in this area. Sainsbury, Kachadoorian, Smith, and Todd (1968) presented data on the nature of cassiterite in the gold placers of Humbolt Creek and suggested nearby areas favorable for lode deposits of tin. The presence of significant amounts of cassiterite in the Humbolt Creek drainage led to reconnaissance and detailed geochemical surveys that showed many anomalous metal concentrations in both alluvial and bedrock materials (Sainsbury, Hudson, Kachadoorian, and Richards, 1970). The following discussion of the nature of the mineralized areas is based on the geologic mapping by the author and geochemical data (Sainsbury, Hudson, Kachadoorian, and Richards, 1970), supplemented by an additional detailed geochemical soil survey in one of the bedrock areas. This part of the report summarizes the nature of the mineralized areas and discusses their spatial and genetic relations to the Oonatut Granite Complex. 


\section{GEOCHEMICAL SURVEYS}

The geochemical surveys included spectrographic analyses of stream sediments, panned concentrates, a few sluice concentrates, and bedrock and soil samples. The results identify many anomalous metal concentrations in bedrock and alluvial materials from a large area directly southeast of the granite complex. No element associations are obviously correlated with the tin anomalies in alluvial materials, but lead, zinc, silver, arsenic, and antimony commonly are associated with tin in bedrock materials.

\section{ALLUVIAL MATERIALS}

A reconnaissance survey of stream sediment $(-80$ mesh) of the entire area identified a few weak tin concentrations, mostly in areas within or directly adjacent to the granite complex. The failure to identify the tin concentrations known to exist along Humbolt Creek (Sainsbury and others, 1968) led to a second more detailed examination of the alluvial materials in the streams draining the eastern part of the area. In this study (Sainsbury, Hudson, Kachadoorian, and Richards, 1970), panned concentrates were found to be particularly useful in detecting important metal concentrations in the stream sediments and in tracing the metal concentrations to their probable source areas.

The detailed study showed that anomalous concentrations of tin are present in sediments of both Humbolt and Ferndale Creeks. The tin anomalies were identified locally along the entire lengths of these streams in the study area, and they head in the hilly areas just southeast of the granite complex. Other metals commonly present in anomalous concentrations are gold, zinc, molybdenum, and locally lead, but the panned concentrates did not reveal any strong correlations between these elements and tin.

\section{BEDROCK MATERIALS}

A search for lode occurrences of cassiterite was undertaken in the bedrock areas between the granite complex and the headwaters of Ferndale and Humbolt Creeks. This search was seriously handicapped by the extensive accumulations of frost-riven rubble that mantles almost all of this area. The geochemical investigations were, therefore, restricted to sampling surface materials, including rock fragments, vein materials, and soils from altered zones. The altered zones were usually identified by surface accumulations of discolored generally iron-hydroxide-encrusted rock or gossan fragments, and especially localized concentrations of fine-grained soil materials in place of the usual rock fragments. Three mineralized bedrock areas were identified with anomalous concentrations of tin, although no definite lode occurrences of cassiterite were found.

The three mineralized bedrock areas are shown in plate 1. The two easternmost areas (localities A and B, pl. 1) are discussed by Sainsbury, Hudson, Kachadoorian, and Richards (1970). The third (locality C, pl. 1) is nearer the eastern contact of the granite complex, and data supplemental to those of Sainsbury, Hudson, Kachadoorian, and Richards (1970) concerning this area are presented here. This zone is defined by discolored and rusty soil materials and ironhydroxide-encrusted fragments that occur adjacent to a very fine grained granite dike that trends No. $80^{\circ} \mathrm{E}$. This dike appears to have been emplaced along a fault, and slickensided fragments of altered rocks present in the surface materials suggest that movement along the fault has been recurrent and in part postdates mineralization. Soil samples, including selected altered rock fragments, were collected along the length of the altered zone, and the results of spectrographic analyses of these samples are listed in table 2. The samples contain highly anomalous amounts of silver, arsenic, lead, antimony, tin, and zinc. This association of elements is present in all three of the principal bedrock mineralized areas. Of these elements, the most abundant are lead and zinc.

\section{SPATIAL AND STRUCTURAL CONTROLS}

The geochemical surveys clearly show that mineralization in the Serpentine Hot Springs area is localized in the hilly area southeast of the granite contact. The wider thermal aureole adjacent to the pluton and observations of the country rock-granite contact indicate that this part of the area is unique because it lies above the unexposed roof of the granite stock. The individual mineralized areas all occur along faults, as is evidenced by the presence of subtle to conspicuous topographic discontinuities, distinctly linear trains of altered rock or soil materials, and the common occurrence of brecciated or slickensided rock fragments in the surface rubble. The most important localizing faults are those that trend northwest, and the major one of these appears to be the throughgoing structure that extends from the headwaters of Humbolt Creek to the central part of the exposed granite complex. This fault splays out in hydrothermally altered rocks of zone 4 . The splays localized the development of the leached leucocratic rocks of facies 4B. It is probable that additional work would locate other mineralized structures, either parallel or subsidiary to the northwest-trending set of fault zones.

\section{SIMILARITIES TO OTHER TIN-MINERALIZED AREAS}

Mineralization in the Serpentine Hot Springs area is similar to that in other tin-mineralized areas in 
TABLE 2.-Results of semiquantative spectrographic analyses of composite grab samples of soil, altered rock, and gossan fragments collected along fault zone containing fine-grained granite dike (locality $C$, fig. 3 )

[K. J. Curry, analyst. All data in parts per miltion. G, greater than value shown. L, detected but below limit of determination. N, not detected. Looked for but not detected: Au, Bi]

\begin{tabular}{|c|c|c|c|c|c|c|c|c|c|c|c|c|c|c|c|c|c|c|c|c|c|c|}
\hline Field No. & Lab. No. & $\mathrm{Mn}$ & $\mathrm{Ag}$ & As & B & $\mathrm{Ba}$ & $\mathrm{Be}$ & $\mathrm{Cd}$ & Co & $\mathrm{Cr}$ & $\mathrm{Cu}$ & $\mathrm{La}$ & Mo & $\mathrm{Nb}$ & $\mathrm{Ni}$ & $\mathrm{Pb}$ & $\mathrm{Sb}$ & Sc & Sn & $\mathrm{Sr}$ & V & $Z n$ \\
\hline $70 \mathrm{AH} 714 \mathrm{~A}$ & BAY001 & $\mathrm{G}(5,000)$ & 15 & 7,000 & 700 & 700 & 7 & 150 & 30 & 300 & 150 & 150 & $\mathrm{~L}$ & 20 & 100 & 5,000 & 500 & 30 & 300 & 150 & 500 & 5,000 \\
\hline $1714 \mathrm{~B}$ & BAY002 & 1,500 & 1.5 & $\mathrm{~L}$ & 300 & 700 & 5 & $\mathrm{~N}$ & 20 & 300 & 100 & 100 & 5 & 20 & 70 & 700 & 200 & 30 & 20 & 150 & 500 & 2,000 \\
\hline $\mathrm{H} 714 \mathrm{C}$ & BAY003 & $\mathrm{G}(5,000)$ & 50 & 7,000 & 500 & 700 & 5 & 150 & 20 & 300 & 500 & 100 & 5 & 20 & 70 & $\mathrm{G}(20,000)$ & 1,500 & 30 & 700 & 150 & 300 & 7,000 \\
\hline $1714 \mathrm{D}$ & BAY004 & 1,500 & 3 & 700 & 700 & 700 & 7 & $\mathrm{~N}$ & 30 & 300 & 200 & 150 & 7 & 20 & 70 & 1,000 & 100 & & 70 & 15 & 500 & 500 \\
\hline $714 \mathrm{E}$ & BAY 005 & $G(5,000)$ & 20 & 10,000 & 300 & 700 & 2 & 200 & 30 & 200 & 200 & 70 & $\mathrm{~L}$ & 20 & 70 & 15,000 & 1,500 & 30 & 500 & 200 & 300 & 10,000 \\
\hline $714 \mathrm{~F}$ & BAY006 & 2,000 & 20 & 500 & 200 & 700 & 7 & $\mathrm{~N}$ & 30 & 200 & 150 & 50 & $\mathrm{~L}$ & 20 & 100 & 15,000 & 700 & 30 & 150 & 20 & 300 & 3,000 \\
\hline $714 \mathrm{G}$ & $B A$ & $G(5,000)$ & 30 & 7,000 & 700 & 700 & 3 & 70 & 30 & 300 & 200 & 150 & $\mathrm{~L}$ & 20 & 100 & 20,000 & 700 & 30 & & & 500 & $G(10,000)$ \\
\hline $714 \mathrm{H}$ & BAY & 5,000 & 3 & 500 & 200 & 700 & 10 & $\mathrm{~N}$ & 30 & 200 & 70 & 70 & $\mathrm{~L}$ & 20 & 100 & 5,000 & 150 & 30 & 50 & & 300 & 1,500 \\
\hline $70 \mathrm{AF}$ & BAY & $G(5,000)$ & 150 & 10,000 & 300 & 700 & 3 & 100 & 30 & 150 & 500 & 70 & $\mathrm{~L}$ & 20 & 70 & $G(20,000)$ & 2,000 & 30 & 500 & 15 & 300 & 7,000 \\
\hline $70 \mathrm{AH}$ & $\mathrm{BAY}$ & 2,000 & 7 & 200 & 200 & 500 & 5 & $\mathrm{~N}$ & 30 & 20 & 70 & 70 & 5 & 20 & 150 & 2,000 & $\mathrm{~L}$ & 3 & 100 & & & 700 \\
\hline $70 \mathrm{AH} 714 \mathrm{~K}$ & BAY011 & 3,000 & 3 & $\mathrm{~L}$ & 300 & 1000 & 7 & $\mathrm{~N}$ & 30 & 300 & 150 & 100 & 5 & 20 & 150 & 1,000 & $\bar{N}$ & 30 & 30 & 15 & 500 & 700 \\
\hline $70 \mathrm{AH} 714 \mathrm{~L}$ & BAY012 & 1,500 & 10 & $\mathrm{~L}$ & 200 & 700 & 5 & $\mathrm{~N}$ & 30 & 300 & 150 & 100 & $\mathrm{~L}$ & 20 & 150 & 2,000 & $\mathrm{~N}$ & 30 & 20 & 150 & 300 & 300 \\
\hline
\end{tabular}

three important ways;

1. The mineralization is in close spatial association with the Oonatut Granite Complex, an epizonal composite biotite granite stock (Hosking, 1968; Sainsbury and Hamilton, 1968). The consistent spatial association of most of the world's major tin deposits with such granite plutons, including some two-mica granites, has long been recognized and has led Sainsbury and Reed (1973, p. 647 ) to conclude that the consistency of this association is analogous to that of chromite deposits and their host ultramafic rocks.

2. The mineralized areas are localized by faults, particularly faults that either transect the granite or localize granite dikes. This type of structure is important in localizing tin deposits in many areas (Hosking, 1968; Sainsbury and Reed, 1973).

3. The suite of elements associated with the bedrock tin anomalies is characteristic of the lead-zinc zone in many tin-mineralized areas. Metal distributions in tin-mineralized areas commonly show a preferred spatial relation to areas mineralized with cassiterite or the associated granite complexes (Dewey, 1925; Sainsbury and Hamilton, 1968). The metal suite present in anomalous concentrations in the bedrock areas southeast of the Oonatut Granite Complex is characteristic of the lead-zinc zone of tin districts, a zone characteristic of the fringe or outer areas of mineralization in the district.

\section{ORIGIN OF MINERALIZATION}

Without additional data, the proposed origin for mineralization outlined here verges on being speculative, but it is consistent with the data presented in this report. The mineralized areas probably originated as the final product in a complex series of magmatic processes. These processes in part included fractional crystallization of the Oonatut Granite Complex, evolution of a residual volatile-rich magma system, and timely fracturing of the pluton margin to allow escape of a coexisting aqueous phase from the residual system. The aqueous phase may have directly led to cassiterite-sulfide mineralization in the higher levels of the cross-cutting faults. Thus, the tin and associated mineralization in the Serpentine Hot Springs area could be a classic example of epigenetic mineral deposits formed by hydrothermal fluids evolved directly by magmatic crystallization.

\section{IMPLICATIONS FOR FUTURE WORK}

Economic lode deposits of cassiterite or other minerals have not yet been identified in the Serpentine Hot Springs area. In evaluating the worthiness of additional minerals exploration in the area, three main possibilities must be kept in mind:

1. The area does not and never did have significant (economic?) lodes of tin or related elements. It has been clearly shown that anomalous concentrations of many elements do exist in the area, and even if the processes responsible for these concentrations are, as believed, the same as those responsible for most of the world's economic tin deposits, it remains uncertain as to whether economic concentrations were formed. The principal unresolved questions in this regard concern such factors as the original tin or volatile content of the granite magma and the efficiency of the granite complex's crystallization in concentrating these elements.

2. Significant (economic?) lode deposits were formed in the area, but they have subsequently been eroded away. The presence of placer cassiterite in Humbolt Creek shows that at least parts of some lode deposits have been eroded.

3. Significant (economic?) lode deposits are present but not identified in the area. The mineralization that has been identified could be interpreted to represent the outer fringes of tin mineralization if the Serpentine Hot Springs area is zoned similarly to some other tin-mineralized districts.

Unfortunately, the available data do not allow satisfactory evaluation of the above possibilities. Because of the nature of the anomalous element suite in the mineralized zones and the spatial relation of the 
mineralized zones to unexposed parts of the granite complex, the possibility of significant tin deposits at depth on the mineralized structures must be seriously considered. The mineralized areas must be better defined and tested at depth for their economic potential.

\section{REFERENCES CITED}

Barnes, D. F., 1971, Preliminary Bouguer anomaly and specific gravity maps of Seward Peninsula and Yukon flats, Alaska: U.S. Geol. Survey open-file map.

Brooks, A. H., Richardson, G. B., and Collier, A. J., 1901, A reconnaissance of the Cape Nome and adjacent gold fields of Seward Peninsula, Alaska, in 1900, in Brooks, A. H., Richardson, G. B., Collier, A. J., and Mendenhall, W. C., Reconnaissances in the Cape Nome and Norton Bay regions, Alaska, in 1900: U.S. Geol. Survey Special Publication, p. 1-185.

Collier, A. J., 1902, A reconnaissance of the northwestern portion of the Seward Peninsula, Alaska: U.S. Geol. Survey Prof. Paper 2, $70 \mathrm{p}$.

$1904 \mathrm{a}$, Tin deposits of the York region, Alaska: U.S. Geol. Survey Bull. 225, p. 154-167.

$1904 \mathrm{~b}$, The tin deposits of the York region, Alaska: U.S. Geol. Survey Bull. 229, $61 \mathrm{p}$.

Collier, A. J., Hess, F. L., Smith, P. S., and Brooks, A. H., 1908, The gold placers of parts of Seward Peninsula, Alaska: U.S. Geol. Survey Bull. 328, 343 p.

Csejtey, Belá, Jr., Patton, W. W., Jr., and Miller, T. P., 1971, Cretaceous plutonic rocks of St. Lawrence Island, Alaska-A preliminary report, in Geological Survey Research 1971: U.S. Geol. Survey Prof. Paper 750-D, p. D68-D76.

Deer, W. A., Howie, R. A., and Zussman, J., 1967, An introduction to the rock-forming minerals: New York, John Wiley \& Sons, $528 \mathrm{p}$.

Dewey, Henry, 1925, The mineral zones of Cornwall: Geologists' Assoc. Proc., v. 36, p. 107-135.

Geotimes, 1973, Plutonic rocks-Classification and nomenclature recommended by the IUGS Subcommission on the systematics of igneous rocks: Geotimes, v. 18, no. 10, p. 26-30.

Hietanen, Anna, 1967, On the facies series in various types of metamorphism: Jour. Geology, v. 75, no. 2, p. 187-214.

Hopkins, D. M., Karlstron, T. N. V. , and others, 1955, Permafrost and ground water in Alaska: U.S. Geol. Survey Prof. Paper 264-F, $146 \mathrm{p}$.

Hosking, K. F. G., 1968, The relationship between primary deposits [of tin] and granitic rocks: Internat. Tin Council, 1st Tech. Conf. on Tin, London, 1967, v. 1, p. 267-311.

Hudson, Travis, 1977, Genesis of a zoned granite stock, Seward Peninsula, Alaska: U.S. Geol. Survey open-file report 77-35, $188 \mathrm{p}$.

Johnson, G. R., and Sainsbury, C. L., 1974, Aeromagnetic and generalized geologic map of the west-central part of the Seward Peninsula, Alaska: U.S. Geol. Survey Geophys. Inv. Map GP881, scale 1:125,000.

Knopf, Adolph, 1908a, The Seward Peninsula tin deposits: U.S. Geol. Survey Bull. 345, p. 251-267. 1908b, Geology of the Seward Peninsula tin deposits, Alaska: U.S. Geol. Survey Bull. 358, 71 p.

Miller, T. P., 1970, Preliminary correlation of Mesozoic plutonic rocks in the Bering Sea region [abs.]: Am. Assoc. Petroleum Geologists Bull., v. 54, no. 12 , p. 2496.

Miller, T. P., Barnes, Ivan, and Patton, W. W., Jr., 1975, Geologic setting and chemical characteristics of hot springs in westcentral Alaska: U.S. Geol. Survey Jour. Research, v. 3, no. 2, p. 149-162.

Moxham, R. M., and West, W. S., 1953, Radioactivity investigations in the Serpentine-Kougarok area, Seward Peninsula, Alaska: U.S. Geol. Survey Circ. 265, 11 p.

Norman, M. B., II, 1974, Improved techniques for selective staining of feldspar and other minerals using amaranth: U.S. Geol. Survey Jour. Research, v. 2, no. 1, p. 73-79.

Sainsbury, C. L., 1969a, Geology and ore deposits of the central York Mountains, western Seward Peninsula, Alaska: U.S. Geol. Survey Bull. 1287, 101 p.

$-1969 \mathrm{~b}$, The A. J. Collier thrust belt of the Seward Peninsula, Alaska: Geol. Soc. America Bull., v. 80, p. 2595-2596.

1972, Geologic map of the Teller quadrangle, western Seward Peninsula, Alaska: U.S. Geol. Survey Misc. Geol. Inv. Map I-685, Scale 1:250,000.

1975, Geology, ore deposits, and mineral potential of the Seward Peninsula, Alaska: U.S. Bur. Mines open-file rept., 108 p.

Sainsbury, C. L., and Hamilton J. C., 1968, Geology of lode tin deposits: Internat. Tin Council, 1st Tech. Conf. on Tin, London, 1967, v. 1, p. 314-349.

Sainsbury, C. L., Hedge, C. E., and Bunker, C. M., 1970, Structure, stratigraphy, and isotopic composition of rocks of the Seward Peninsula, Alaska [abs.]: Am. Assoc. Petroleum Geologists Bull., v. 54, no. 12, p. 2502-2503.

Sainsbury, C. L., Hudson, Travis, Kachadoorian, Reuben, and Richards, Thomas, 1970, Geology, mineral deposits, and geochemical and radiometric anomalies, Serpentine Hot Springs area, Seward Peninsula, Alaska: U.S. Geol. Survey Bull. 1312-H, 19 p.

Sainsbury, C. L., Kachadoorian, Reuben, Smith, T. E., and Todd, W. C., 1968, Cassiterite in gold placers at Humbolt Creek, Serpentine-Kougarok area, Seward Peninsula, Alaska: U.S. Geol. Survey Circ. 565, 7 p.

Sainsbury, C. L., and Reed, B. L., 1973, Tin: U.S. Geol. Survey Prof. Paper 820, p. 637-651.

Sigafoos, R. S., 1958, Vegetation of northwestern North America, as an aid in interpretation of geologic data: U.S. Geol. Survey Bull. 1061-E, p. 165-185.

Spry, Alan, 1969, Metamorphic textures: New York, Pergamon, $350 \mathrm{p}$.

Steidtmann, Edward, and Cathcart, S. H., 1922, Geology of the York tin deposits, Alaska: U.S. Geol. Survey Bull. 733, 130 p.

Turner, F.J., 1968, Metamorphic petrology-mineralogical and field aspects: San Francisco, McGraw-Hill, 403 p.

Wahrhaftig, Clyde, 1965, Physiographic division of Alaska: U.S. Geol. Survey Prof. Paper 482, 52 p.

Wright, T. L., 1968, X-ray and optical study of alkali feldspar, II. An X-ray method for determining the composition and structural state from measurement of $2 \theta$ values for three flections: Am. Mineralogist, v. 53, p. 88-104. 


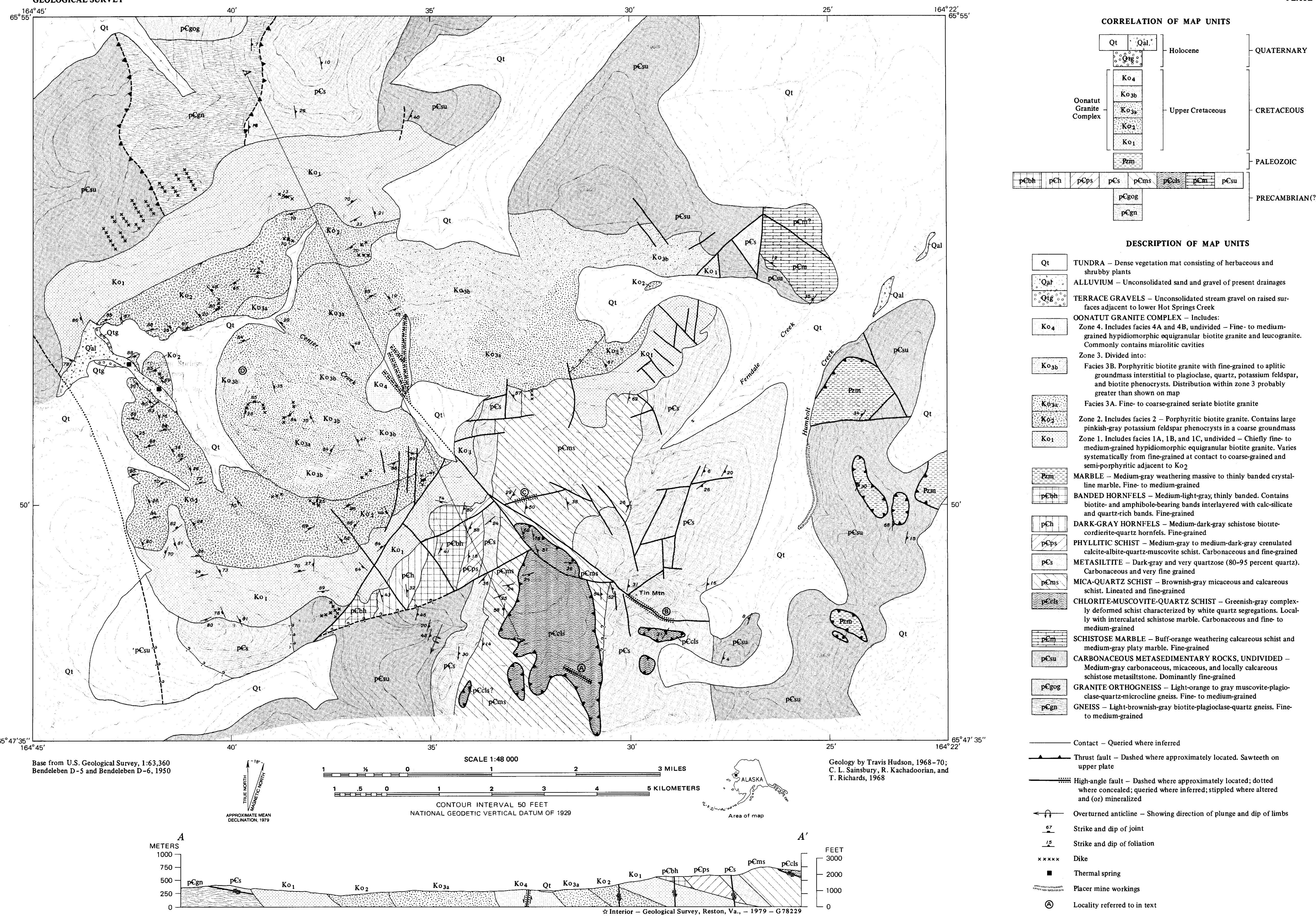

